\title{
Tradição Oral e produção de narrativas
}


Waldemar Ferreira Netto

\section{Tradição Oral e produção de narrativas}

http://dx.doi.org/10.4322/978-85-99829-26-4

$1^{a}$ edição atualizada

\section{Paulistana \\ 〜 Editora}

São Paulo 2009 
Copyright by Waldemar Ferreira Netto

Editora responsável

Adélia Maria Mariano da S. Ferreira

Capa

William de Paula Amado

Diagramação

Selma Consoli Mtb 28.839

Revisão

Adélia Maria Mariano da S. Ferreira

Rosane de Sá Amado

Infothes Informação e Tesauro

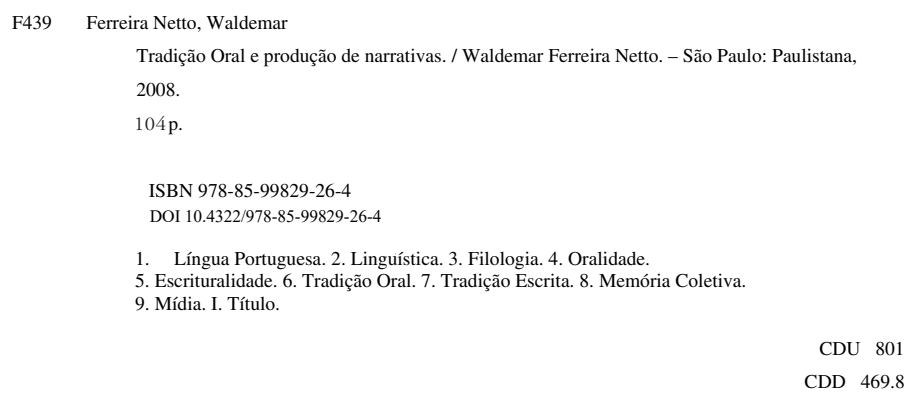

1. Língua Portuguesa. 2. Linguística. 3. Filologia. 4. Oralidade.

5. Escrituralidade. 6. Tradição Oral. 7. Tradição Escrita. 8. Memória Coletiva.

9. Mídia. I. Título.

CDD 469.8

Catalogação elaborada por Wanda Lucia Schmidt - CRB-8-1922

Nenhuma parte desta publicação pode ser reproduzida ou transmitida por qualquer processo eletrônico, mecânico ou fotográfico, incluindo fotocópia, xerocópia ou gravação, sem a autorização prévia e escrita da Editora.

Todos os direitos desta edição reservados à

\section{Paulistana}

$\sim$ Editora

Editora Paulistana Ltda

Rua Artur de Azevedo, 2.100 sala 3 Pinheiros

05404-005 São Paulo - SP

www.editorapaulistana.com.br

[2009]

$1^{\text {a }}$ edição atualizada: outubro de 2009 


\section{Sumário}

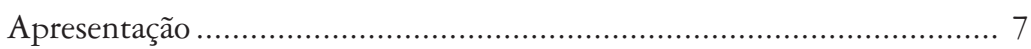

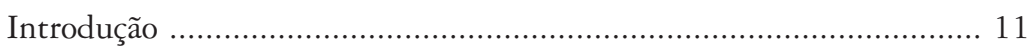

Memória coletiva e narrativas coletivas …………………………....... 19

Halbwachs entre a Tradição Oral e a História .................................... 29

Aspectos linguísticos das narrativas orais

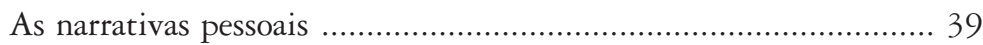

A transformação da narrativa ........................................................ 52

A adequação dos modelos comportamentais exemplares ................ 73

A substituição dos meios de comunicação ......................................... 80

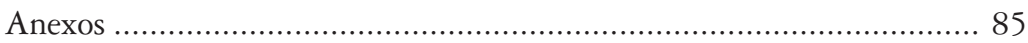

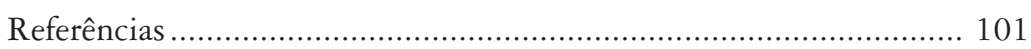




\section{Apresentação}

Depois de alguns anos também como professor de uma das disciplinas do curso básico de Letras (Introdução aos Estudos de Lingua Portuguesa II), habilitação Português, da Universidade de São Paulo, cujo conteúdo é língua falada, Waldemar teve a feliz ideia de fazer este livro, em que expõe seu ponto de vista sobre o conceito e a prática da oralidade. É preciso dizer da importância e relevância das intervenções do autor perante um grupo de colegas que trata do assunto com base em perspectiva teórica diversa da sua. Aos poucos, e com perseverança, os colegas ouvíamos comentários sobre a necessidade de fazer nossos alunos conhecerem "o outro lado da oralidade", na verdade o primeiro lado, o da oralidade "pura" sem submissão à escrita. É disso que ele vem falar, agora para um público maior do que o dos colegas e de seus alunos.

Não seria preciso falar da relevância do autor no cenário da Linguística, mas falar coisas boas de bons profissionais e de bons colegas nunca é excessivo. Por isso, alardeio aqui o quanto é prazeroso compartilhar o ambiente de trabalho com Waldemar, pois além de um professor-pesquisador sério, honesto e competente, é um colega solidário, que não se guarda apenas para as suas pesquisas e afazeres individuais e é alguém que se envolve com a vida universitária. 
No campo da pesquisa, destaco a atuação de nosso autor em dois domínios que, embora inter-relacionados, têm as suas especificidades: o da Linguística e o da Etnolinguística. No primeiro, labora atualmente, como fonólogo e foneticista, analisando questões da língua portuguesa; e, no segundo, atuou com mais intensidade nos anos 90 do século anterior, especialmente no tangente à descrição de sistemas fonológicos de línguas indígenas. Essa experiência, como linguista dedicado às línguas de minorias indígenas, o fez um pouco antropólogo, etnólogo e sociólogo, lhe conferiu a autoridade que tem para falar da "oralidade primária", como o faz neste volume.

Por isso, sem medo de estar blefando, asseguro ao leitor que este livro traz uma posição diferente da que estamos habituados a ver sobre a oralidade. Waldemar vem a público para chamar a atenção para o fato de a oralidade das sociedades letradas (pelo menos as ocidentais modernas) ser submissa à "escrituralidade". A hipótese do autor é a de que só é possível observar, nesse tipo de sociedade, a oralidade primária, espontânea, solta, livre e desvinculada do domínio da escrita em momentos específicos de interação, como naqueles de grande intimidade entre os falantes. Em outras situações de interação, com algum grau de formalidade, os falantes se submetem a regras mais rígidas, que os fazem construir textos mais complexos, típicos do domínio da escrita.

O leitor precisa ficar atento para o fato de Waldemar considerar a fala e a escrita como mídias, assim com as demais às quais estamos habituados a nos referir: o rádio, a televisão, o cinema, a imprensa etc. Isso é importante porque, como para as demais, a atualização do enunciado não será a mesma em todas as mídias. Logo, como é fácil perceber, a realização da língua e a consequente elaboração do texto serão submetidas a injunções impostas pela mídia pela qual é expressado. O leitor percebe que, desse modo, se fala das "modalidades linguísticas, falada e escrita”, com base em outro referencial teórico, e tal diferença é essencial ao entendimento da proposta do autor, que vai além das 
diferenças formais, ou seja, de marcas linguísticas, entre a oralidade e a "escrituralidade".

Nesta obra, como se percebe desde as primeiras linhas, fica patente que o objetivo do autor é caracterizar a oralidade como um fenômeno bio-psico-social integrado. Por que bio-psico-social? e por que integrado? Para ser exata, ou coerente à proposta do livro, não deveria explicar de modo separado cada uma dessas partes, já que têm de ser entendidas com um todo, e daí advém a importância de se afirmar ser este um fenômeno integrado. Por razões metodológicas e didáticas, todavia, tem-se de comentar cada uma dessas partes em separado.

A tese do autor, tributária de outras já defendidas por Maurice Halbwachs, é a de que a oralidade, entendida como fenômeno tão amplo e natural ao homem como a língua/linguagem que usa, é dependente da memória, coletiva e individual. Esse é o ponto decisivo para a explicação do que afirmamos acima. Por isso, primeiro, se a memória é localizada no cérebro e aí tem uma base física, é um fenômeno biológico. Depois, se é individual e coletiva, está atrelada a fatores psíquicos e psicológicos inerentes ao falante que se expõe aos acontecimentos, à própria vida, e que vai aprendendo a falar e a selecionar o que lhe é pertinente para formar a memória discursiva que o levará a falar (e a escrever, no caso das sociedades letradas). Finalmente, se a oralidade depende igualmente da memória coletiva, tem a sua contraparte social e histórica, já que a linguagem é um comportamento social e, como tal, dependente das normas e regras que regem o convívio social. Não é à toa que Herculano de Carvalho, importante linguista português, diz que "o homem fala como os outros falam”, o que pode ser atribuído tanto às sociedades letradas como às não-letradas, ou ágrafas.

É principalmente a partir dessa base que Waldemar opera para tratar da oralidade. O leitor perceberá logo que neste livro o termo oralidade tem dois referentes. Um é o da oralidade tal como a ela estamos 


\begin{abstract}
Waldemar Ferreira Netto
habituados a pensar, em se tratando da realização oral da língua nas sociedades letradas. A esse sentido o autor recorre somente para construir, por oposição, o sentido que lhe interessa, o segundo, que, como explica muito bem, é, em verdade, o primeiro, sob o ponto de vista ontológico. Essa, então, é a oralidade "pura" em relação à não-vinculação com a cultura-escrita. Essa oralidade é tratada no livro como tradição oral.

A apresentação e o desenvolvimento dessas ideias fazem-se de modo leve e provocativo. $\mathrm{O}$ autor vai, numa escrita bem coerente com o que pensa, conversando com seu leitor, levando-o a "labirintos", fazendoo refletir sobre questões complexas, para enredá-lo, conquistá-lo, ou, quem sabe, fazê-lo um pesquisador da área. Vale a pena verificar tudo o que o livro revela.

Essa é uma leitura, portanto, que interessa a todos os interessados na linguagem: professores, alunos, pesquisadores e o público em geral.
\end{abstract}

São Paulo, 14 de julho de 2008.

Marli Quadros Leite

Universidade de São Paulo / CNPq 


\section{Introdução}

Embora hoje estejamos mais acostumados ao trato com as formas letradas de documentação e uso da língua, tendo a oralidade apenas como forma acessória e adequada somente para momentos específicos, cheios de informalidades e de familiaridades, temos de adotar um ponto de vista diferente para entendermos como foi que esse processo se deu. De maneira mais geral, essa oralidade vai aparecer, por exemplo, nas brigas, nas piadas, nas relações amorosas íntimas, nas fofocas pessoais, dificilmente isso vai ocorrer em outros momentos. Nos demais momentos, como em quase todos os momentos, a oralidade que ocorre está baseada em textos escritos. Uma conversa informal por si só não tem de ser um fato da oralidade. Na maior parte das vezes, discute-se o que se leu, o que se viu na TV, ou que se viu no cinema, que são mídias muito diferentes da oralidade, porque têm suas regras próprias para serem elaboradas. Esses fatos, segundo essa hipótese, não seriam da mesma "oralidade" que estou tentando abordar. Não se trata somente de existir um som que sai da boca, mas também dos assuntos, dos pressupostos, da maneira de abordagem, das estratégias de memorização e de uma porção de outras coisas que são muito diferentes entre as duas formas de "oralidade". Como o termo cunhado para essas duas coisas é "oralidade", estou usando da forma geral que se usa quando se 
fala em Tradição Oral. Desse ponto de vista, a oralidade no contexto letrado só existe em nichos muito singulares, como uma sobrevivência de tempos remotos, fossilizados pelo descaso sobre eles.

Nossa hipótese mais geral é a de que foi com a oralidade que a linguagem humana, tal como a conhecemos hoje, teve a sua origem, em que pesem outras possibilidades como, por exemplo, a língua de sinais. Plenamente viável, a língua de sinais, também como a conhecemos hoje, teve uma origem posterior, recente, como meio de comunicação. A fala, exclusivamente oral e duplamente articulada, desenvolveu-se muito precocemente dentre os meios de comunicação humana, mas, ao que parece, muito tardiamente no próprio desenvolvimento humano. Isso não tem como pressuposto que o homem fosse silencioso, incapaz de comunicar-se. Sem dúvida deveria fazê-lo. Mas podemos pensar que, nesses primórdios, o homem não se comunicava por meio de uma fala duplamente articulada, tal como fazermos.

Um sistema linguístico sem dupla articulação parece-nos hoje inviável, mas não há o que o impeça de existir: as escritas ideogramáticas, com perfeita capacidade expressiva, não se articulam duplamente, mas baseiam-se numa linguagem que é duplamente articulada. Ora, voltamos ao início. Podemos buscar outras formas de comunicação: os ideofones não têm dupla articulação, mas também não formam frases completas; a prosódia não tem dupla articulação, mas também não tem perfeita capacidade expressiva. E se juntarmos tudo isso, ideofones, prosódia, grafismos, gestos, dentre muitas outras possibilidades de sistemas de comunicação, não poderíamos suprir as necessidades de comunicação do homem pré-falante? Não sei, nem sei se teremos como descobrir.

O fato é que a dupla articulação é um fenômeno próprio da linguagem humana e só da linguagem humana, pelo menos até agora. Lidar com duas instâncias de informação a um só tempo, como na linguagem duplamente articulada, parece ser uma propriedade exclusivamente humana. De um lado, percebo e analiso os sons, de 
outro agrupo-os e associo o conjunto a uma experiência passada. Presente e passado a um só tempo. Isso não é novidade, afinal quaisquer símbolos se prestam a isso. A questão se dá quanto à própria natureza do símbolo. Não se trata de um som associado a um momento do passado, mas de uma distribuição específica de sons tomada conjuntamente. É o signo saussuriano. Entre a percepção do som e sua associação com uma experiência memorizada, há um processamento intermediário de análise e síntese. A partir daí, seria possível a combinatória exaustiva de todos os sons, para a criação infinita de associações entre sons combinados e experiências memorizadas. No texto do Curso de Linguística Geral, quando aparece a frase "O papel característico da língua frente ao pensamento não é criar um meio fônico material para a expressão das ideias, mas servir de intermediário entre o pensamento e o som...". ${ }^{1}$ De fato, o que vai nesse trecho é a ideia de que o signo se reporta simultaneamente ao pensamento, que se funda em experiências no presente e do passado, e ao som que se ouve naquele exato instante da enunciação. As duas instâncias da informação seriam, portanto, a do significante (do som difuso e amorfo para a imagem acústica) e a do significado (das ideias amorfas e indistintas para o conceito), ambas ocorrendo simultaneamente, ou com mínimas diferenças de milissegundos.

Mas não é só isso, mesmo a hipotética linguagem monoarticulada que estamos postulando para nossos ancestrais permitiria a criação infinita de sons com experiência memorizada. Se, de fato, tiver havido essa linguagem, certamente isso teria acontecido. E não há razão para negarmos esse fato. Ora, foram muitos milhares de anos, milhões de anos, andando pelo mundo, é bem provável que alguma coisa como essa tenha se desenvolvido. Mas, por algum motivo qualquer, durante o

1 (SAUSSURE, 1977, p. 131, da trad. da Cultrix). No texto original, encontra-se "Le rôle caractéristique de la langue vis-à-vis de la pensée n'est pas de créer um moyen phonique matériel pour l'expression des idées, mais de servir d'intermédiaire entre la pensée et le son..." 
período das glaciações, descobriu-se a novidade da dupla articulação. Talvez num só lugar, dando origem a todas as línguas do mundo, talvez em vários lugares ao mesmo tempo, dando várias origens às línguas do mundo. $\mathrm{O}$ fato é que essa mudança deve ter ocorrido durante o longo período das glaciações, quando apareceram as primeiras manifestações simbólicas massivas do homem. Nesse período, mais do que um sujeito duplamente articulado com grande capacidade expressiva, o homem se torna também um sujeito social, passando a desenvolver o convívio social de forma sistemática e institucionalizada. Nesse caso, poderíamos correlacionar o aparecimento das sociedades ao aparecimento da dupla articulação ${ }^{2}$ Nova especulação para a qual não tenho nenhuma resposta. Mas também não há nada que me permita contrariar isso. O período anterior à dupla articulação seria a pré-história da pré-história humana.

Ao que parece estou zanzando num labirinto, cujas saídas eu não descobri. Deve haver algumas espalhadas por aí. Sejam lá quais forem, não deixa de ser notável que, durante muitas centenas de milhares de anos, o homem não tivesse percebido que podia desenvolver grafismos, ou que podia falar. Mas isso não assusta, durante milhares de anos, depois que aprendeu a escrever, o homem também não percebeu que poderia representar as emoções de forma iconográfica na escrita. Foi preciso um desenvolvimento tecnológico da maior sofisticação para que ele percebesse isso. Depois, está claro, essa representação iconográfica das emoções na escrita pôde ser feita facilmente com qualquer lápis e papel. Mas nós não percebemos isso. Ao que parece

2 Leakey (1997), que faz uma excelente discussão sobre isso, lembra a hipótese de Holloway (1983) quando este afirmara que "a linguagem cresceu a partir de uma matriz socialcomportamental-cognitiva que era fundamentalmente cooperativa e não agressiva, e repousava sobre uma divisão social estrutural complementar do comportamento em relação ao trabalho entre os sexos". Leakey (1997) ainda reproduz mais um trecho do trabalho de Holloway (1983): "Isso era uma estratégia evolutiva e adaptativa necessária para permitir um período de dependência infantil prolongado, períodos prolongados até atingir a maturidade sexual, uma maturação retardada que permite um maior crescimento do cérebro e aprendizado comportamental." (tradução minha) 
também o homem pré-pré-histórico não se dera conta de que poderia fazer grafismos, representações simbólicas. Mas aprendeu, e nós mesmos somos as consequências disso.

Aprender a lidar com as próprias capacidades é um fato corriqueiro para os humanos, principalmente durante os primeiros anos de vida. Nem tudo é fácil de se aprender, até andar, que deveria ser o mais intuitivo possível, não é. Temos de aprender a andar. Ao que parece, temos de aprender a usar nossas próprias capacidades cognitivas, fazendo as conexões que devem ser feitas, as mesmas que fizeram nossos avós e que ora nos ensinam nossos pais e demais coetâneos. Não é um aprendizado fácil, pois assim como não é fácil ensinar a movimentar as pernas para ficar em pé, não é fácil promover conexões específicas entre sons e experiências memorizadas. $\mathrm{O}$ máximo que podemos fazer para ensinar alguém a movimentar as pernas para ficar em pé é ficarmos em pé, ou ajudá-lo a ficar em pé, e esperar que sirva de exemplo, que ele perceba como fazer a força e as conexões corretas e que consiga buscar o equilíbrio correto para isso. $\mathrm{O}$ aprendiz é o autor do aprendizado e nós somos meros coadjuvantes cuja função principal é apenas desencadear a necessidade da aprendizagem.

O processo de aprendizagem do uso do próprio corpo não é coisa ainda completamente conhecida. $\mathrm{O}$ fato é que tudo passa pelo sistema nervoso central, pelo córtex, de um lado, de outro, volta, vai, ziguezagueando até nos darmos conta de que sabemos. Se tentamos fazer alguma coisa pela primeira vez, ficamos inseguros, mas, na vez seguinte, já saberemos um pouco, o suficiente para repetir o que já fizemos. E, na outra, com o conhecimento cada vez mais consolidado, seremos hábeis para reproduzir comportamentos com mais exatidão, prevendo todas as etapas que se sucedem nessa repetição de comportamentos. De fato, já teremos na memória o comportamento futuro; o que parece um paradoxo não é mais do que a nossa capacidade de reproduzir comportamentos, antecipando nossas ações, tanto para realizá-las como para corrigi-las quando necessário. Nesse caso, a 
aprendizagem se confunde com a capacidade de memorizar e de se recuperar o que se memorizou.

Apesar de estarmos nos reportando à memória como um fenômeno próprio do ser humano e, ainda, aqui e ali, de tratarmos dela como um fenômeno fisiológico, a ideia de que vamos mais propriamente ao encalço é a de que a memória é um fenômeno cognitivo do ser humano, muito provavelmente correlata a fenômenos fisiológicos que recebem nome semelhante, cuja propriedade mais específica é atuar como elemento formador da identidade pessoal e coletiva. Entendemos que a memória que vai descrita aqui é um fenômeno de natureza cultural adquirido no correr do desenvolvimento pessoal e social dos indivíduos e de suas sociedades. Desse ponto de vista, é um comportamento aprendido a partir de capacidades biológicas próprias e transmitido entre as diferentes gerações. Por se tratar de uma instituição social, a memória tem uma função própria dentro da sociedade que se diferencia entre as sociedades; por se tratar de uma capacidade diretamente correlacionada à fisiologia do ser humano, ela é um fenômeno universal que se reproduz necessariamente em todas as sociedades.

Dentre as características mais notáveis da memória, está o fato de poder ser recuperada a partir de estímulos externos incidentes no corpo de seu portador. É possível diferir memória explícita de memória implícita. A memória explícita envolve a lembrança consciente de episódios passados, por meio da recuperação intencional desses episódios, enquanto a memória implícita envolve a influência de episódios passados no comportamento atual sem recuperação intencional e, algumas vezes, sem lembrança consciente daqueles episódios. $^{3}$ Assim, não somente o indivíduo tem poder sobre a sua

Tradução minha. No original: "Explicit memory involves conscious remembering of prior episodes, often by means of intentional retrieval of those episodes, whereas implicit memory involves influences of prior episodes on current behavior without intentional retrieval, and sometimes without conscious remembering of those prior episodes." (SCHOTT et alii, 2005) 
memória, mas também os outros. A memória poder ser manipulada de fora implica que a própria identidade seja um fenômeno que se desenvolva na sociedade. Para a manipulação da própria memória, o próprio indivíduo aprende a manipular os estímulos incidentes que lhe permitem simular o ambiente que desencadearia as lembranças próprias do momento daqueles estímulos.

As diferenças na manipulação da memória entre os indivíduos e entre as sociedades estão diretamente relacionadas à história de cada um deles, pois são estratégias que se desenvolveram no correr do tempo, de acordo com as experiências e necessidades de cada um. Por ser um fenômeno cognitivo, tem a restrição de apenas se tornar pública nas suas manifestações físicas na forma das linguagens disponíveis para isso. Dentre essas linguagens, a língua é uma das que melhor propicia a sua exteriorização. De maneira geral, antes dessa exteriorização numa forma de linguagem qualquer, pouco se pode afirmar a respeito dela, sequer a sua existência.

Uma das possibilidades estratégicas de manipulação institucional de comportamentos que se dá no contexto de uma sociedade de Tradição Oral, ou mesmo nas suas formas remanescentes no interior de uma sociedade de Tradição Escrita, são as narrativas que se transmitem entre todos os membros e entre as gerações de um mesmo grupo. As narrativas orais são, a um só tempo, fenômenos típicos tanto da memória implícita quanto da explícita. Lembramo-nos de uma narrativa quando queremos, e para isso basta que saibamos o seu início ou que tenhamos à mão alguma forma de desencadearmos a sua lembrança automaticamente. Essa forma de documentação de eventos na memória individual é um dos meios institucionalizados próprios das sociedades para garantirem a sua identidade e a sua permanência. Conforme se demonstrará mais adiante, o meio utilizado pelas sociedades de Tradição Oral é a oralidade, valendo-se das memórias coletiva e individual, e o das sociedades de Tradição Escrita são os documentos permanentes, sejam eles escritos ou não, estabelecendo a memória histórica. 
Neste trabalho não me ative a essa forma de documentação permanente, senão aqui e ali, quando foi estritamente necessário. Ao contrário, dei toda a ênfase à Tradição Oral, especialmente quanto às narrativas produzidas nesse contexto. Para tanto, fiz uma apresentação resumida das formas próprias de manutenção de identidade social, buscando as propostas de Ralph Linton e de Erwin Goffman, e das características próprias de uma sociedade que se vale exclusivamente da oralidade para manter essa identidade, buscando as propostas de Jack Goody e Ian Watt e de Marshall McLuhan para caracterizá-las. Em seguida, para estabelecer os princípios formais e analisáveis, busquei a proposta de Maurice Halbwachs quanto à memória coletiva, que estabelece os mecanismos subjetivos próprios para a formação de uma rede de conhecimentos simbólicos memorizados. Nesse sentido, bem como em todo o livro, estarei tomando a noção de "rede" como a manutenção de um fato institucional memorizado total ou parcialmente por todos os indivíduos que pertencem ao mesmo grupo. Suas memórias individuais, tomadas coletivamente, formam a rede de conhecimentos que sustenta a identidade do próprio grupo. Na medida em que estarei considerando que as narrativas são fenômenos importantes na manutenção dessa identidade, apresentarei as propostas de William Labov e de Jerome Bruner para as análises específicas dessa forma de documentação. 


\section{Memória coletiva e narrativas coletivas}

Num dos seus trabalhos que se tornaram clássicos, LeGoff(1990) faz a distinção entre os conceitos de documento e monumento. Segundo ele, "monumento é tudo aquilo que pode evocar o passado, perpetuar a recordação" (p. 535). Os monumentos seriam os desencadeadores da recordação, atuando diretamente, do ponto de vista deste nosso trabalho, como um estímulo externo para a recuperação da memória. $\mathrm{O}$ monumento é o gatilho oficial para a lembrança de fatos específicos estabelecidos pela sociedade, que se mantêm armazenados na memória coletiva. Assim, o monumento dispara a recordação de narrativas determinadas socialmente, quer como fato político, religioso, moral, quer como de mero entretenimento.

Muito embora estejamos acostumados a pensar nos monumentos como peças esculturais espalhadas pela cidade, o alcance desse conceito parece ser ilimitado. Desde os nomes próprios dados às pessoas e aos locais, os quais despertam laços familiares ou feitos próprios dos ancestrais, bem como os comportamentos ritualísticos das práticas nos cultos religiosos que promovem as lembranças das narrativas ancestrais referentes àqueles comportamentos, até mesmo as pinturas figurativas ou as tatuagens simbólicas, dentre muitos outros exemplos possíveis, os monumentos podem atuar como disparadores de lembranças de 
narrativas institucionalizadas pela memória coletiva. Os monumentos atuam, portanto, como complementação à memória que não se sujeita às vontades do indivíduo, mas exige o apoio externo para sua manipulação. Isso torna a memória individual também sujeita à manipulação externa, social, uma vez que o domínio dos fatos extraindividuais pode tanto ser público como pessoal. Desse ponto de vista, o conceito de monumento descobre a ação reguladora da memória no sentido de propiciar lembranças coletivas, simultâneas e específicas de cada comunidade.

A noção de documento, segundo LeGoff (1990), após ter passado por várias interpretações, afirma-se somente no século XX, estendendose, assim como foi com a noção de monumento, para todas as coisas que, de uma forma ou de outra, permaneceram do passado até a atualidade. A noção atual de documento, que teve como berço a História Nova dos Analles, ${ }^{4}$ pressupõe obviamente a permanência dos dados, cujo suporte midiático ofereça as condições adequadas para isso. Difere dos monumentos no que diz respeito a seus propósitos sociais: o monumento é um gatilho para recordações, o documento é o conjunto dos dados específicos dessas recordações. Assim, a noção de documento pressupõe a de leitura ativa, diferentemente da noção de monumento, que apenas pressupõe a de lembrança passiva dos fatos desencadeada por um estímulo externo.

No âmbito da oralidade, monumento e documento confundemse na memória coletiva e nas práticas sociais institucionalizadas. Documento e monumento complementam-se como estratégias específicas dessas sociedades para salvaguardar as informações legadas pelos antepassados. Assim, o acesso ao(s) documento(s) portador(es) de informação decorre do disparo feito pelo monumento específico para ele(s). O domínio na manipulação dos monumentos é, portanto, prática crucial para a sociedade e para a sua manutenção de identidade

${ }^{4}$ Para maiores informações sobre essa escola, cf. Le Goff (1990). 
própria que mantém o grupo coeso, padronizando o comportamento de seus membros. Desse ponto de vista, não há que se confundirem as estratégias baseadas na memória coletiva de uma sociedade em que a tradição oral é predominante, daquela baseada na memória histórica de uma sociedade em que a tradição escrita é predominante.

A proposição dessa ruptura entre as duas fôrmas culturais, a Tradição Oral e a Tradição Escrita, permite a compreensão das estratégias estabelecidas entre as diferentes sociedades para a manutenção de sua identidade e consequentemente a sua própria coesão como uma sociedade diferenciada de uma multidão reunida para um mesmo propósito, como uma torcida de futebol. A esse respeito Linton (1981) já havia proposto no começo do século XX, nos anos trinta, descrevendo o funcionamento da sociedade, que essa dependesse da existência de padrões de comportamento recíproco entre indivíduos de um mesmo grupo. Segundo ele, esses padrões de comportamento assumidos pelos indivíduos são chamados tecnicamente de status, os quais têm deveres e direitos, socialmente definidos. O status decorreria das posições sociais ocupadas durante a vida de um indivíduo em uma comunidade. A efetiva realização dos direitos e deveres do status seria o papel desempenhado pelo indivíduo. O status tanto poderia ser adquirido, como atribuido. Segundo Linton (1981), o status atribuído seria determinado por referências alheias às capacidades do indivíduo: sexo, idade, casta, relações de parentesco; adquirido seria decorrente das capacidades adquiridas pelo indivíduo como resultado do esforço pessoal e da competitividade interpessoal. O autor ainda propôs que tais fenômenos caracterizem a formação de uma sociedade, diferenciada de um agregado de indivíduos, na medida em que essa formação pressupõe "(1) acomodação e organização do comportamento dos indivíduos... (2) desenvolvimento de uma consciência de grupo, um sentimento de unidade". Dessa maneira, a proposta de Linton (1981) é a de que a sociedade tenha de salvaguardar do esquecimento, estabelecendo um vínculo constante entre as diversas 
gerações, o conjunto de status e de seus papéis correspondentes cuja função é a que vai descrita em (1) e em (2) acima — para o seu funcionamento.

De um ponto de vista um pouco diferente, e alguns anos depois, no final dos anos cinquenta, Goffman (2005) propôs que o indivíduo (ator social) tivesse duas espécies diferentes de atividade comunicativa: a expressão simbólica intencional e a expressão sintomática nãointencional deduzida pelos observadores (ou co-participantes da situação) da ampla gama de comportamentos produzidos pelo indivíduo. Goffman (2005) propôs, também, que a presença simultânea de vários indivíduos estabelece uma situação na qual um indivíduo procura expressar suas características sociais (e individuais) com a expectativa de ser tratado e valorizado de acordo com os deveres e direitos que se associam a essas características, renunciando a todos os direitos e deveres que outras características poderiam demandar. O conjunto determinado das características que demandam deveres e direitos foi proposto como papel social; e as atividades expressivas, intencionais ou não-intencionais, do ator social, como desempenho. Dessa maneira, podemos dizer que, segundo Goffman (2005), um ator social em determinada situaşão desempenha um papel a partir do qual quer ser avaliado pelos coparticipantes, à semelhança do que ocorre numa cena teatral (a situação), na qual os atores (o ator social) interpretam (o desempenho social) personagens (o papel social) pelo qual querem ser avaliados pela plateia (co-participantes).

A noção de papéis sociais da proposição de Goffman (2005), com seus direitos e deveres, permite-nos associá-la à de status da proposição de Linton (1981); e a de desempenho de Goffman (2005), à de papel de Linton (1981). Com o propósito de evitar confusões terminológicas, podemos assumir ad hoc que papéis sociais abarquem as noções de status, seja atribuido, seja adquirido, guardando o termo status para a rotulação proposta por Linton (1981) referente à soma de todos os papéis (ou status para esse autor) ocupados por um indivíduo na sociedade. Dessa 
maneira, podemos entender que o status de um indivíduo socialmente considerado é a composição cumulativa de todos os papéis que ele tem de desempenhar para manter sua posição na organização de uma sociedade.

Não podemos ainda, antes de tratar das implicações linguísticas dessas análises, nos furtar da relação que se pode estabelecer entre os conceitos aqui apresentados, e a proposição de Barth (1998) quanto ao estabelecimento de uma identidade étnica. Segundo o autor, o reconhecimento de um grupo étnico dá-se pelo reconhecimento de fatores socialmente relevantes estabelecidos pelos próprios membros desse grupo, a partir não só de sinais ou signos culturais objetivos que as pessoas exibem para demonstrar sua identidade, mas, principalmente, pelos padrões de moralidade e de excelência pelas quais as ações são julgadas. Barth (1998), nos anos sessenta, propôs que membros de um grupo queiram ser tratados, interpretados e julgados a partir dos padrões de moralidade e de excelência a que pretendem sujeitar-se. A proposição de Barth (1998) vai ao encontro do estabelecimento do status de Linton (1981) e o dos papéis sociais de Goffman (2005). A aceitação de padrões de moralidade e de excelência de Barth (1998) pressupõe não só o conhecimento desses padrões, mas também os limites que eles estabelecem para formar as diferenças entre o que desejam ser e o que não desejam ser os membros de um determinado grupo social, ou de um determinado grupo étnico.

Podemos pensar, portanto, que a sociedade se organiza pela distribuição de papéis sociais entre seus membros, que devem sujeitarse ao conjunto de comportamentos previamente definidos e também à avaliação do alinhamento que produzam entre o desempenho de suas atividades e a idealização própria de cada um desses papéis sociais. Nesse caso, a idealização própria dos comportamentos atribuídos a cada um desses papéis sociais faz parte do conjunto móvel de signos e sinais culturais objetivos (BARTH, 1998) dispersos numa complexa rede de significações que deve se manter institucionalizada, a despeito 
dos meios de transmissão que sejam seus portadores. Todos os membros do grupo conhecem os indivíduos, os papéis respectivos e as formas próprias de desempenhá-los, e são capazes de julgar esses desempenhos com base nos mesmos critérios socialmente estabelecidos. A mobilidade desse conjunto é um pressuposto necessário para a adequação perfeita da transformação social e, com ela, a dos seus papéis sociais organizadores. A dinâmica da mudança dos padrões de moralidade e de excelência, dos direitos e dos deveres, deve igualmente ter seu reflexo na rede institucional de significações, de forma a orientar o desempenho dos papéis sociais realizado pelos membros da sociedade.

Goody e Watt (2006), também na década de sessenta, propuseram que o reflexo da transformação social manifesta-se nas readequações dos meios de transmissão às novas necessidades, por exemplo, na readequação dos mitos de origem, na reformulação das genealogias, na inserção de novas passagens, e assim em diante. Mas, para além dessas mudanças, os autores propuseram que a própria transformação dos meios de transmissão também se reflita nas transformações sociais, dessa feita, na reorganização dos papéis sociais e dos status dos membros do grupo. Na medida em que a mudança dos meios caracteriza-se pela mudança na disponibilidade dos conjuntos de signos e sinais culturais dispersos na rede de comunicação, há que pensar também, ainda a partir da hipótese de Goody e Watt (2006), que o próprio meio dessa rede atua como elemento de coesão social promovendo o contato entre os diversos membros que têm de ter acesso a ele para garantir o alinhamento de seu desempenho comportamental com a idealização dos papéis adquiridos ou que lhe foram atribuídos.

Também nos anos sessenta, McLuhan (1979) propôs que a mensagem de qualquer meio ou tecnologia é a mudança de escala, cadência ou padrão que esse meio ou tecnologia introduz nas coisas humanas, tratando-se, pois, do resultado da implementação de características formais específicas de um meio para outro. A invenção da dupla articulação para a fala, a impressão com tipos móveis da 
imprensa para a escrita manuscrita, ou a narrativa oral para o cinema ou a televisão, poderiam servir como exemplos diversos dessas mudanças, na medida em que o texto impresso alcança um número muito maior de pessoas do que o texto manuscrito, mas o cinema e a televisão conjugam imagem, som, movimento e fala como expressão física enquanto a narrativa escrita exige do próprio leitor a criação subjetiva desses fatos. Também podemos pensar que a interpretação dos meios teria de envolver a percepção das diferenças e das semelhanças que existem entre eles, de maneira consciente ou não. Segundo essa hipótese, a comunicação ocorreria em camadas independentes, mas sustentadas umas sobre as outras. A análise de aspectos formais específicos de um meio desvendaria os mecanismos de implementação utilizados para manter conteúdos primários precedentes. Do ponto de vista dessa sucessão de implementos formais, a descrição do meio assume a característica de proximidade maior com as etapas predecessoras. Nesse caso, será necessário desvendar as características formais (mensagens) que se acrescentaram a seu conteúdo de maneira que seja possível buscar as camadas sucessivas de sustentação da linguagem. Na medida em que a implementação dessas características não permite a substituição completa de sua camada de sustentação, pode-se postular que, além da informação comum a todos os meios que se acumularam, haverá supressões e acréscimos na passagem de uma camada a outra. Tais supressões e acréscimos podem ser considerados tanto ruídos como aprimoramentos no processo comunicativo.

A se aceitar as propostas de Goody e Watt (2006) e McLuhan (1979), podemos imaginar que a mudança na disponibilidade dos conjuntos de signos e sinais culturais dispersos na rede de comunicação caracteriza-se pela mudança de escala, cadência ou padrão que esse meio ou tecnologia introduz nas coisas humanas, apresentando variações historicamente significativas na rede institucional de significações que porta os padrões de moralidade e de excelência, dos direitos e dos deveres. Entende-se, pois, que a mudança no perfil da rede institucional 
de significações pode atuar diretamente no comportamento dos membros de um grupo social, na medida em que esses devem sujeitarse ao conjunto de comportamentos previamente definidos e também à avaliação do alinhamento que produzam entre o desempenho de suas atividades e a idealização própria de cada um desses papéis sociais. Para o acesso ao texto escrito exige-se não somente a alfabetização, mas também o papel e a tinta, para o acesso às narrativas do cinema, exigemse as máquinas, as películas, as salas de projeção, além da própria produção material da narrativa, por meio dos diretores, atores, roteiristas... Nesse caso, compare-se o acesso imediato da narrativa oral entre a sua produção e a percepção e a narrativa cinematográfica. Dessa maneira, a intenção comportamental de um indivíduo será um reflexo intermediado da transformação da tecnologia envolvida no meio de comunicação. Nesse caso, os intermediários serão as possibilidades de acesso à rede de significações, cujas mudanças na forma de supressões ou acréscimos tecnológicos exigem que os membros do grupo social estejam aptos para sua reanálise.

A manutenção da rede institucional de significações que estabelece os padrões comportamentais dos papéis organizadores da sociedade dá-se por meio de dois processos básicos fortemente relacionados: a adequação de modelos comportamentais exemplares pela retroalimentação e a substituição dos meios de informação pela transformação tecnológica. A adequação dos modelos comportamentais exemplares é a resposta social ao impacto da mudança efetiva que reflete a experiência bem ou mal sucedida dos membros da sociedade. Tratase, portanto, de uma mudança na rede que ocorre a posteriori. A substituição dos meios de informação, por sua vez, é o resultado $a$ priori da inserção de novas tecnologias que geram novas dificuldades ou facilidades no acesso à rede institucional de significações e aos modelos comportamentais exemplares que ela carrega.

A manutenção e a divulgação dos papéis sociais entre os membros de um grupo qualquer dá-se, no contexto de uma sociedade de Tradição 
Tradição Oral e produção de narrativas

Oral, ou mesmo nas suas formas remanescentes no interior de uma sociedade de Tradição Escrita, por meio de sua documentação em narrativas que se transmitem a todos membros e entre as gerações de um mesmo grupo. 


\section{Halbwachs entre a Tradição Oral e a História}

Halbwachs (1990), em sua proposta de Memória Coletiva, estabeleceu três conceitos específicos para a memória: a individual, a coletiva e a histórica. Segundo ele, dessas três memórias, somente a memória individual pode ser tomada como original, tendo em vista ser a que foi gerada por uma testemunha do fato. No entanto, a memória individual é fragmentária e não comporta uma reconstituição precisa do fato que se testemunhou. ${ }^{5}$ A memória coletiva seria o resultado de uma reconstrução de memória individual da qual participaram todos os membros de uma mesma comunidade que foram testemunhas dos mesmos acontecimentos que formam o conjunto que se reconstrói. Dessa maneira, a partir de um conjunto de memórias individuais

\footnotetext{
Essa concepção da memória humana de Halbwachs permanece atual. Autores como Damásio (1996, p. 130) corroboram essa ideia: "O que as representações dispositivas armazenam em suas pequenas comunidades de sinapses não é uma imagem per se, mas um meio para reconstruir um esboço dessa imagem"; Rosenfield (1994, p. 80-1) afirma também que "Não existem recordações específicas em nosso cérebro; existem apenas meios de reorganizar as impressões passadas, de dar ao mundo incoerente e onírico da memória uma realidade concreta. As memórias não são fixas, mas sim generalizações recriações do passado que estão em constante evolução, dando-nos um sentimento de continuidade, um sentimento de existência com passado, presente e futuro."
} 
fragmentadas, forma-se uma imagem mais completa dos acontecimentos passados. A memória histórica é a reconstrução do passado tomando por base os eventos que foram efetivamente documentados e que permitem uma reconstrução exata do passado. A memória coletiva e a histórica, em que pese terem sido construídas a partir de memórias individuais, são mediadas pela conversão da experiência testemunhal em uma outra linguagem e, portanto, estão sujeitas a todo tipo de influência externa no seu estabelecimento. Se, por um lado, a memória individual é a única verdadeiramente confiável, por outro, ela é fragmentária; se, por um lado, as memórias coletiva e histórica não são confiáveis, por outro, são as que se apresentam com maior precisão e poder explicativo.

A memória individual - e mesmo a coletiva, entendendo-se que decorreu do amalgamento de diversas memórias individuais opõe-se diretamente à memória histórica, na medida em que ela é coetânea dos eventos a que se refere. De maneira geral, na memória individual, mais que na coletiva, o enunciador é protagonista, talvez coadjuvante, nos eventos narrados. Seu testemunho carrega mais do que a própria descrição do fato, carrega também a sua avaliação emocional dos acontecimentos. A seleção dos eventos que formam o conjunto dos eventos memorizados depende diretamente da carga emocional que receberam (HAMANN et alii, 1999) e, nesse caso, espera-se que os eventos emocionalmente mais significativos tenham um estatuto privilegiado para a memorização.

Apesar de a memória individual receber contribuição significativa de outros indivíduos, — o que a torna sempre uma composição entre eventos efetivamente lembrados pelo indivíduo e eventos narrados por terceiros —, a memória individual é sempre tomada como específica de si própria. Desse ponto de vista da composição híbrida da memória individual, entende-se que seu caráter fragmentário exige o preenchimento constante dos "silêncios" do passado para a configuração de um todo coerente e passível de ser 
explorado. ${ }^{6} \mathrm{~A}$ fonte primeira para tais preenchimentos advém da própria vida social que fornece o contato interpessoal e a constante troca de informação. É essa troca, na forma de interlocuções, que atua como geradora de fatos e eventos memorizáveis que completam as memórias efetivamente individuais. $\mathrm{O}$ amalgamento, entretanto, é perfeito e imperceptível. O sujeito se torna, então, portador de fatos memorizados de que não tinha conhecimento, ou se já os tivera, deixara de tê-lo, mas que na interlocução se tornam efetivamente parte de sua memória individual.

Facilmente se percebe que, na memória individual, haverá fatos que se repetem entre vários indivíduos que participam da mesma comunidade de interlocução geradora desses mesmos fatos memorizados. As memórias, dessa maneira, se associam pela comunhão de lembranças comuns que permitem, por sua vez, o reconhecimento e a familiaridade entre todos os membros participantes dessa comunidade. A memória coletiva que subjaz a todas as memórias individuais atua, portanto, como um conjunto de referências interpessoais que estabelece a unidade do grupo portador dessas mesmas referências. Halbwachs refere a memória coletiva como séries de datas ou listas de fatos históricos que servem de referência para a organização das memórias individuais em seu processo de reconstrução.

A distinção entre a memória coletiva e a histórica, por sua vez, parte de sua forma documental. A memória coletiva resulta da troca verbal de informações entre os indivíduos coevos, na medida em que sofre das restrições próprias da mídia na enunciação que promove o relato das experiências pessoais entre interlocutores. Fala-se da boca para o ouvido diretamente, exigindo a presença simultânea dos

6 Rosenfield (1994, p. 210) lembra Edelman e afirma que "toda pessoa é única: suas percepções, até certo ponto, são criações, e suas lembranças fazem parte de um processo contínuo de imaginação. A vida mental não pode ser reduzida a moléculas. A inteligência humana não consiste apenas em saber mais, porém em reelaborar, recategorizar e, com isso, generalizar as informações de maneiras novas e surpreendentes." 
indivíduos que reorganizam suas memórias. Diferentemente se faz com a memória histórica, que, apesar de também sofrer de restrições da mídia, tem um resultado cumulativo, no eixo do tempo e do espaço. $\mathrm{Na}$ medida em que nenhuma delas exige o testemunho pessoal do narrador, a diferença entre memória coletiva e memória histórica resulta, portanto, da variação da mídia portadora da experiência.

A memória coletiva, bem que o nome aponte para o grupo, é, de fato, individual, pois depende do indivíduo para sua manutenção. Desse ponto de vista, a memória coletiva ganha mais uma restrição, que é a fugacidade do próprio indivíduo. A duração da memória coletiva é menor ou igual à duração do indivíduo. Ultrapassar esses limites será decorrência do estabelecimento de sua constante divulgação para outros indivíduos, que acrescentam, na medida do possível, os fatos memorizados pelo narrador aos seus próprios, reconstruindo assim a própria memória coletiva, agora acrescida das contribuições do ouvinte.

Na memória histórica, ainda que a mesma contribuição do ouvinte possa ocorrer, essa contribuição tem uma escala muito diferenciada. A memória histórica é cumulativa, os relatos das testemunhas dos primeiros eventos acumulam-se aos relatos das testemunhas dos eventos seguintes e assim sucessivamente. A reconstituição dos eventos do passado tem de poder fixar-se definitivamente, ou poder ser questionada para que uma nova reconstituição seja proposta, mas, ainda assim, ambas as reconstituições serão cumulativas e poderão servir de base para uma terceira reconstituição. Esse acesso reiterado ao passado resulta da possibilidade de documentação cumulativa que a mídia utilizada deve possuir. Muito diferente da mídia utilizada pela memória coletiva, que não aceita reiterações interindividuais, mas tão-somente a substituição do relato anterior pela nova reconstituição que se fez daquele. Dado seu poder cumulativo, a memória histórica permite a reanálise de qualquer momento do passado, com acesso imediato a ele. Desse ponto de vista, Goody (1988, p. 165-166) lembrou que a "emergência do que nós 
chamamos história está intimamente ligada à introdução da escrita, como, aliás, a distinção da pré-história implicitamente sugere”. A utilização da mídia escrita permite a manutenção cumulativa das informações a que nos referimos. Da mesma maneira, o mesmo autor ainda frisa que essa manutenção cumulativa não é suficiente por si só, mas que a "emergência da história não depende apenas da existência de arquivos ou da formalização da informação", ela "exige ainda uma atenção crítica aos originais e aos comentários tecidos pelos diversos autores, sobretudo quando é possível confrontar diferentes versões". (op. cit. p. 166)

Na memória coletiva, e por consequência também na individual, o acesso aos eventos do passado exige a interpretação constante das referências definidas coletivamente. Essa reinterpretação possibilita, por sua vez, a variação das mesmas, estabelecendo narrativas que nem sempre se superpõem. Ao contrário, as narrativas seguem, cada qual, seu próprio curso, adaptando-se continuamente pelas necessidades do momento e pelas restrições dos indivíduos. Somente as memórias individuais narradas pela testemunha efetiva dos eventos têm referências particulares. No entanto, o próprio evento da enunciação, da criação da narrativa, contribui para a memória coletiva, bem como para sua própria transformação e atualização. Nesse caso, a memória individual e a sua narrativa correspondente têm vida curta, persistindo exatamente o mesmo tempo de sua enunciação ou de seu enunciador, caso esse a replique noutros momentos. A narrativa individual, da experiência pessoal, caminha sempre para o passado assim como seu enunciador, agrupando-se às demais narrativas que já se enunciaram no passado e que permanecem como resíduos na memória coletiva dos indivíduos vivos.

Esse fenômeno estabelece um paradoxo, na medida em que o destino de todas as narrativas e de seus eventos será sempre o tempo dos antepassados. Como todas as narrativas morrem junto de seus narradores, o destino das narrativas futuras será exatamente esse mesmo 
tempo dos antepassados. ${ }^{7}$ A circularidade do presente nas narrativas pessoais opõe-se à linearidade das narrativas do passado dependente da memória coletiva, que acumula referências. Assim, passado e presente não se confundem quanto ao curso do tempo, uma vez que o passado tem o presente como destino e o presente tem o passado como destino. Apesar disso, o passado tem início e o presente, não, daí a circularidade deste, e a linearidade daquele (cf. Figura 1).

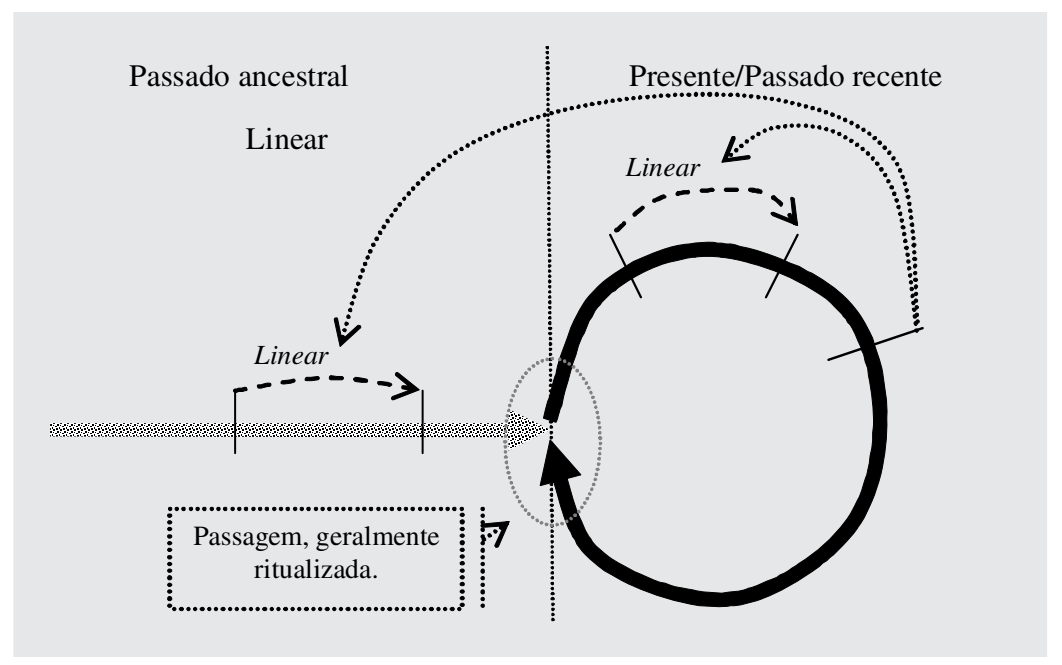

Figura 1: Imagem que procura representar o passado como uma concepção de tempo linear (linha difusa) e o presente (linha contínua) como uma concepção de tempo circular. A linha pontilhada vertical mostra o limite entre eles, e o círculo com linha pontilhada o momento da passagem do passado ancestral para o presente e do presente para o passado ancestral. As linhas perpendiculares aos eixos temporais de passado ancestral e de presente/passado recente mostram momentos

\footnotetext{
Em relação às culturas Bantas, na África, Kagame (1975) já havia salientado que "os mortos, tanto os mais recentes quanto os distantes, concluíram sua trajetória existencial de 'Vivos'. Sob esse ponto de vista, eles se situam no 'passado', o que na realidade significa que suas atividades marcaram o tempo anterior, à medida que se sucediam as gerações que terminaram sua marca de 'Vivos”. (p. 116-7)
} 
específicos de uma enunciação-narração. No eixo temporal à direita, uma das linhas mostra o momento da enunciação e as setas pontilhadas indicam os eixos temporais lineares das narrativas que estariam sendo enunciadas.

Como se pode notar na Figura 1, o ponto de passagem do passado para o presente sobrepõe as concepções do passado narrativo, que são as referências mantidas pela memória coletiva, e do presente individual vivo, que pode conter as narrativas individuais referentes não ao passado ancestral, mas ao tempo das experiências pessoais vividas pelo próprio narrador. ${ }^{8}$ Assim, dois passados serão necessários, o passado ancestral e o passado das experiências pessoais, o passado recente. No ponto de passagem específico, marcado na figura acima pelo círculo pontilhado, tem-se as mortes simultâneas das narrativas pessoais e de seus narradores, estes ancestralizando-se, aquelas assumindo sua porção na memória coletiva do grupo. Nesse ponto se fecha o círculo do presente e se alonga a linha difusa do passado.

O tempo circular do presente está diretamente associado ao curso nascimento $\rightarrow$ vida $\rightarrow$ morte (ou sentença restritiva $\rightarrow$ sentença complicadora $\rightarrow$ coda, numa sentença narrativa, como se verá mais adiante) de cada indivíduo. Durante esse processo, há narrativas que descrevem tanto fragmentos que ocorreram na vida do próprio enunciador, as narrativas pessoais, como há narrativas que descrevem/ reproduzem narrativas que teriam sido fragmentos da vida de outros. As narrativas que descrevem fragmentos da vida do enunciador

8 Bergson (2006) já tinha dito que se considerarmos "o presente concreto e realmente vivido pela consciência, pode-se dizer que esse presente consiste em grande parte no passado imediato. Na fração de segundo que dura a mais curta percepção possível de luz, ocorreram trilhões de vibrações, a primeira das quais está separada da última por um intervalo enormemente dividido. Sua percepção, por mais instantânea que seja, consiste portanto numa incalculável quantidade de elementos rememorados e, na verdade, toda percepção já é memória. Na prática, percebemos apenas o passado, sendo o presente puro o inapreensível avanço do passado roendo o porvir." (grifos do autor, p. 90) 
ocorrerão necessariamente em $1^{\mathrm{a}}$ pessoa, porque ele próprio foi testemunha dos fatos narrados, quer como protagonista, quer como coadjuvante. As narrativas que descrevem fragmentos da vida de outros ocorrerão necessariamente em $3^{a}$ pessoa, porque o enunciador não foi testemunha do fato, nem coadjuvante.

$\mathrm{Na}$ medida em que a narrativa no presente circular/passado recente teve o enunciador como testemunha, ela terá de estar completamente de acordo com o contexto do enunciador. A narrativa pessoal do presente circular tem caráter autobiográfico e, por isso mesmo, tem de representar um conjunto de imagens objetivas e bem situadas nesse tempo. Por ser autobiográfica, tem de realizar-se no passado recente. Daí, podemos definir que tais narrativas devem ocorrer no modo verbal do passado perfeito e imperfeito, pelo menos na língua portuguesa.

Considerando-se o fato de que a distinção entre a memória histórica e a memória coletiva e a individual diferem especialmente quanto à sua forma documental, podemos entender que a diferença de concepção do tempo é também uma consequência dessa mídia portadora das narrativas. A mídia própria das memórias coletiva e individual é a oralidade e a mídia da memória histórica são os documentos permanentes, sejam eles escritos ou não. Grosseiramente, podemos considerar ambos a partir das noções de Tradição Oral e Tradição Escrita, em que pese o fato de a Tradição Escrita compreender outras formas de documentação além da escrita.

Goody e Watt (2006) registraram essa ideia, apesar de não tratarem diretamente da circularidade do presente, atentando para o fato de que "o conteúdo completo da tradição social aparte as heranças materiais é armazenado na memória" (p. 16). Nesse caso específico, segundo eles, "a memória individual será mediada pela herança cultural, de tal maneira que seus novos constituintes se ajustarão aos antigos (...) e quaisquer partes dele que tenham parado de ter relevância nesse momento são provavelmente eliminadas pelo processo de esqueci- 
mento" (id. ib.). A interpretação do passado, segundo os autores, será, portanto, além de seletiva quanto aos fatos que serão mantidos, conforme já dissemos, também seletiva quanto aos fatos que serão eliminados. Em ambos os casos, o que se transforma são as narrativas referentes ao passado que, na consciência do grupo, representam a história de si próprios, sua própria origem.

Acompanhando as propostas de Halbwachs (1990) e de Goody e Watt (2006), Ong (1998) propôs a existência da oralidade primária e da verbalização escrita. Segundo o autor, oralidade primária seria a oralidade de culturas não afetadas pela cultura escrita, das pessoas que a desconhecem inteiramente, e a verbalização escrita seria a oralidade das culturas e das pessoas afetadas pela escrita, entendendo-se que "afetadas", nesse caso, reporta-se à prática socialmente instituída da escrita. A ideia de institucionalização da escrita é fundamental para a compreensão da oralidade primária. Noutro trabalho, salientei que a presença da escrita durante séculos junto a alguns grupos indígenas no Brasil não produziu a institucionalização da escrita no grupo. ${ }^{9}$ Nesse caso, deve-se considerar que a institucionalização da escrita não se dá pela sua presença na comunidade, mas pelo seu uso coletivo continuado de forma a servir de suporte físico a uma grande maioria de formas de transmissão de conhecimentos. ${ }^{10}$ A distinção proposta por Ong (1998)

9 "Em que pese o seu passado nas repúblicas jesuíticas, ou em outras reduções, cujas marcas são visíveis em vários aspectos de seu comportamento, a escrita permaneceu como um fenômeno desconhecido e desejado, sem jamais ter sido incorporado. Várias tentativas isoladas foram realizadas no decorrer dos séculos, com sucesso somente para indivíduos, mas nunca para o grupo." (FERREIRA NETTO, 1994, p. 8)

10 Essa institucionalização da escrita como prática social e individual difundida entre a maioria dos membros de um mesmo grupo é comumente referida como letramento. A forma "letramento", como tradução da forma inglesa literacy, foi retomada para expressar essa institucionalização e estendeu-se a todas as áreas do conhecimento, pelo menos no Brasil, como a expressão da institucionalização cultural; assim, atualmente é possível falar em "letramento musical", "letramento", "letramento literário", "letramento matemático”, dentre outros. Domingos Vieira, em 1873, definia letramento como "sm. ant. lettra, escriptura". 


\section{Waldemar Ferreira Netto}

exige a reinterpretação do conjunto de práticas linguísticas próprias da oralidade, procurando estabelecer igualdades e diferenças entre suas manifestações como oralidade primária ou oralidade secundária, entendendo-se esta última definição como a verbalização escrita que o autor propôs. ${ }^{11}$

${ }^{11}$ Cf. especialmente Gnerre (1998), para uma crítica às propostas de Goody e Watt (2006), e Marcuschi (2001), para uma apresentação dos teóricos e de seus motivos para a crítica a essa proposta. 


\section{Aspectos linguísticos das narrativas orais}

\section{As narrativas pessoais}

Tendo em vista a distinção feita a partir das concepções de memória coletiva por Halbwachs (1990) e por Goody e Watt (2006), podemos estabelecer que a memória individual esteja restrita à circularidade temporal do presente circular. A distinção entre as duas tradições, Oral e Escrita, no caso particular da memória individual, não se faz produtiva, uma vez que a mesma só se manifesta a partir da necessidade das referências ao passado ancestral linear. Tomados independentemente, tanto o presente como o passado remoto têm características temporais semelhantes, em que há o encadeamento linear de eventos. Somente quando o presente tem de se encadear no passado, ocorre a perda da linearidade temporal, e há a necessidade de distinção entre um passado remoto e um passado recente. Assim, as narrativas históricas, da memória histórica, e as narrativas orais, da memória coletiva, confundem-se mutuamente nas narrativas pessoais.

Para a caracterização dessas narrativas pessoais, que seriam decorrentes da memória individual, pode-se tomar a proposição de Labov (1997): 
0. experiência pessoal;

1. organização temporal da narrativa: juntura temporal, sentença sequencial, narrativa minima, sentença narrativa e modo realis;

2. tipos temporais de sentenças narrativas: raio de ação da sentença narrativa, sentença livre, sentença presa;

3. tipos estruturais de sentenças narrativas: resumo, orientação, complicadora e coda;

4. avaliação: sentença avaliadora, modo irrealis;

5. relatabilidade: evento relatável, evento mais relatável, reatribuição de turno;

6. credibilidade: paradoxo da credibilidade;

7. causalidade: teoria pessoal da causalidade;

8. atribuição do elogio e da culpa;

9. ponto de vista: narrador, contador, não-flashback;

10. objetividade: evento objetivo, evento subjetivo;

11. resolução: marca de finalização.

A definição de Labov (1997) para a narrativa pessoal exige que se trate de um tipo especial de narrativa que tenha sido efetivamente vivida pelo enunciador-narrador. ${ }^{12}$ Trata-se, portanto, de uma definição que exclui todas as demais narrativas em que o enunciador-narrador não tenha participado. É nosso interesse neste trabalho, entretanto, apreender o conjunto de definições de narrativa pessoal proposto por Labov (1997) para aplicá-las em outro objeto, que não se constituirá

${ }^{12}$ Estamos tomando a noção de enunciador conforme vai descrito em Benveniste (1989). Quanto ao narrador, trata-se de uma figura linguística desenvolvida pelo enunciador por meio da manipulação do código. Desse ponto de vista, quando tratarmos de narrativas pessoais, teremos sempre um enunciador-narrador, na medida em que entendemos que ambos os conceitos estão a referir-se à mesma pessoa. Quando não houver essa coincidência, usaremos as formas enunciador ou narrador isoladamente. 
necessariamente como narrativas pessoais no molde proposto por esse autor. O princípio que perseguiremos será justamente o do ilusionismo próprio da realidade virtual em que o enunciador-narrador é capaz de simular as características da realidade por meio da manipulação da mídia incidente nos sentidos de seu interlocutor. Nesse caso, a restrição imposta ao enunciador-narrador estará vinculada às características própria da mídia em questão e ao domínio que o enunciador-narrador tem sobre elas. Dessa maneira, entendemos que a simulação do enunciador-narrador permite a perfeita reprodução do enunciadornarrador que tenha efetivamente vivenciado os eventos narrados, tal como preconiza Labov (1997), uma vez que esse mesmo enunciadornarrador tenha um perfeito domínio da mídia que utiliza.

A narrativa pessoal, para Labov (1997), estabelece os conceitos de juntura temporal, de sentenças sequencial, livre e narrativa e o de narrativa minima. Segundo ele, uma juntura temporal é o vínculo que se estabelece entre duas sentenças cuja ordem não possa ser invertida, sob o risco de uma mudança de sentido. Desse ponto de vista, a juntura temporal é a perfeita correlação entre a ordem das sentenças e a ordem cronológica dos eventos que são apresentados em cada uma delas. Dessa maneira, pode-se dizer que a ordem cronológica das sentenças numa narrativa oral terá de se correlacionar perfeitamente com a ordem cronológica dos eventos apresentados em cada uma delas; mas, numa narrativa escrita, a correlação não se dará no mesmo eixo temporal, mas em dois eixos: espacial para a disposição das sentenças e temporal para os eventos apresentados em cada uma delas. Na medida em que é nosso propósito entendermos especialmente a narrativa oral, podemos estabelecer que o vínculo entre as sentenças e seus respectivos eventos dá-se na mesma dimensão temporal.

As sentenças sequenciais são as que se vinculam numa juntura temporal, isto é, aquelas cuja ordem de aparecimento temporal está correlacionada à ordem de ocorrência dos eventos que apresentam. Esse conjunto de sentenças vinculadas em juntura temporal, Labov 
(1997) chamou de sentença narrativa; o que estabelece por si só que uma sentença narrativa mínima tem de contar com pelo menos uma juntura temporal para sua própria definição e, se a juntura temporal é a correlação temporal entre duas sentenças e dois eventos, entende-se que o conceito de narrativa mínima deve-se à própria definição de juntura temporal e de sentença narrativa. A narrativa mínima será, portanto, constituída de duas sentenças sequenciais vinculadas numa juntura temporal. Para que possam ser consideradas numa juntura temporal, as sentenças sequenciais têm de preencher determinados requisitos: narrador e enunciador têm de ser o mesmo indivíduo (mas, se não for uma narrativa pessoal, narrador e enunciador não podem ser o mesmo indivíduo); verbos em modo realis (modo indicativo, tempos presente e passado perfeito ou imperfeito) e apresentação objetiva (priorização de substantivos).

As sentenças livres, por sua vez, são as que não estão vinculadas numa juntura temporal, formando uma sentença narrativa, mas podem ser inseridas entre as sequenciais, independentemente, para complementar alguma informação.

Ainda segundo Labov (1997), na medida em que a sentença narrativa é eminentemente uma descrição de eventos temporalmente sequenciados, ela se constitui de sentenças sequenciais formadas no modo realis, isto é, que apresentam fatos como se efetivamente tivessem ocorrido. Na língua portuguesa, à semelhança do que propõe Labov (1997) para o inglês, esse modo é principalmente o passado perfeito, ou o presente com função de passado, ainda que se dê preferência para aquele.

Para uma sentença narrativa formada por determinadas sentenças sequenciais, ele define raio de ação como esse conjunto específico de sentenças sentenciais que formam uma sentença narrativa. Desse ponto de vista, todas as sentenças que formam uma sentença narrativa são presas à sentença antecedente e à subsequente, com exceção da primeira e da última. Essa primeira sentença sequencial, presa somente à 
subsequente, é definida por Labov (1997) como sentença restritiva, que serve como cabeça de uma sentença narrativa. Pode-se dizer que o desencadeamento da sentença narrativa depende do sucesso dessa sentença restritiva, uma vez que ela é decisiva para seu início.

Uma sentença livre, por sua vez, não tem juntura temporal e, portanto, não pode participar de uma sentença narrativa, mas tem o seu valor de verdade mantido durante todo o desenvolvimento da sentença narrativa. Uma narrativa, portanto, caracteriza-se, segundo Labov (1997), por ser um conjunto de sentenças restritivas, presas e livres.

Labov (1997) propõe também que, além dessa classificação, as sentenças possam ser classificadas mediante o tipo de consideração que faz em relação à narrativa; podem ser: resumo, de orientação, de ação complicadora e coda. A sentença de resumo é uma sentença livre e inicial, que, segundo Labov (1997), descreve uma sequência de eventos da narrativa. Da mesma maneira, uma sentença de orientação, também sentença livre, dá informações sobre o tempo, lugar, identidade e comportamento inicial dos participantes, dentre outras possibilidades. Essas sentenças, de resumo e de orientação, atuam na forma de estabelecer o pano de fundo da narrativa, formando uma base que orienta o ouvinte na sua interpretação da narrativa.

Além desses dois tipos propostos por Labov (1997) para sentenças livres, ele propõe que as sentenças presas, as sequenciais, possam ser classificadas também como de ação complicadora e de coda. As sentenças de ação complicadora são praticamente todas as que fazem o encadeamento narrativo, por meio de junturas temporais, com exceção da primeira e da última. A primeira sentença é dada como restritiva, como já se viu, e a última é uma sentença de coda. A sentença de coda é a sentença de finalização da sentença narrativa. Pode ser tanto uma sentença presa, com juntura temporal somente em relação à sua antecedente, como uma sentença livre, disposta no final de uma narração, mas sem contar com juntura temporal, na medida em que não precisa manter a 
correlação temporal própria das sentenças sequenciais que formam uma sentença narrativa.

Segundo Labov (1997), as sentenças de uma narrativa podem assumir um caráter avaliativo e assim podem ser classificadas como sentenças avaliadoras. Nesse caso, pode-se dizer que as sentenças avaliadoras são principalmente sentenças livres, na medida em que não têm de estar correlacionadas numa juntura temporal. As sentenças avaliadoras, ao contrário das sequenciais, formam-se no modo irrealis, que, na língua portuguesa, manifesta-se pelo uso principalmente do subjuntivo, mas pode manifestar-se também pelo indicativo nas formas de imperfeito, condicional, futuro, dentre outras possibilidades. Embora Labov (1997) não faça referência a esses detalhes linguísticos específicos, entende-se que a variação entre os modos realis e irrealis seja própria dos recursos de cada língua e que seu domínio apresenta-se como fato fundamental para o controle do enunciador-narrador na elaboração da narrativa.

De maneira geral, Labov (1997) refere a mídia especificamente quando descreve as características da narrativa serem em modo realis ou irrealis, uma vez que a sua formação está diretamente associada a fenômenos morfológicos ou lexicais da língua em questão. Entretanto, a referência ao ato da enunciação propriamente dito ocorre em vários momentos da proposição de Labov (1997). Trata-se da concessão de turno ao enunciador-narrador pelos interlocutores-ouvintes, pois, na medida em que há durante todo o tempo o perigo de se ter a fala cortada por interlocutores insatisfeitos com a narrativa, o enunciadornarrador deve estar atento aos sinais de aprovação ou de reprovação manifestos por sua plateia para que possa orientar sua produção narrativa no sentido de obter maior aprovação e, assim, conseguir concluí-la. Segundo Labov (1997), os temas de maior interesse (sexo, morte, questões morais) podem oferecer um apoio maior para a manutenção da narrativa e, dessa maneira, podem atuar como mídia para outros propósitos. No entanto, o monitoramente da atenção dos interlocutores- 
ouvintes é imprescindível, mesmo em se tratando de narrativa em que esses próprios temas sejam o objeto da narrativa, constituindo-se no evento mais relatável.

Umas das características principais propostas por Labov (1997) refere-se à definição de evento mais relatável. Essa definição aparece no texto de Labov (1997) associada à de evento relatável e à de reatribuição de turno ao falante. A noção de evento mais relatável é justamente o ponto de chegada de uma sentença narrativa. Na medida em que, para fazer uma narrativa, o enunciador-narrador terá de apropriar-se da fala durante mais tempo do que seria o comum entre interlocutores, e terá, ainda, de obter a atenção silenciosa de seus interlocutores, será necessário que esses mesmos interlocutores permitam que isso ocorra, tratando-se, pois, de um acordo feito ad hoc, justificado pela segurança de que todos que permanecerem silenciosamente atentos ouvindo a narrativa do enunciador-narrador serão recompensados pela apresentação de um evento interessante que trará algum tipo de satisfação. Para receber esse benefício, o enunciador(futuro)narrador tem de produzir uma sentença que apresente um evento relatável, que desperte o interesse, a curiosidade de seus ouvintes e, assim, consiga estabelecer o acordo ad hoc para que possa tomar a fala por um tempo mais demorado que os demais. Assim, os demais interlocutores reatribuem-lhe o papel de enunciador, permitindo-lhe fazer a narrativa. De fato, um evento relatável é a promessa de um evento mais relatável. Pode-se pensar que o evento relatável é a sentença restritiva que encabeça uma sentença narrativa e que o evento relatável é o evento final dessa sentença narrativa; os eventos intermediários seriam os complicadores de ação.

Labov (1997) propõe que os eventos mais relatáveis são geralmente os que tratam de morte, de sexo e de indignações morais. Embora essa possa ser uma constante em nossa sociedade, podemos imaginar que haja uma grande variedade de objetos apropriados para se tornarem eventos mais relatáveis em outras sociedades. 
Conforme já se disse no início dessa discussão, para Labov (1997) as narrativas pessoais têm de ser exclusivamente aquelas vividas pelo enunciador-narrador, na medida em que será somente nesse caso que, além do interesse a ser justificado pelo evento mais relatável, os interlocutores aceitarão reatribuir o turno ao enunciador-narrador. Desse ponto de vista, Labov (1997) chama a atenção para o fato de que quanto mais fantástico for o evento relatável, tanto menor será a credibilidade que se dará para ele.

A proposta de Labov (1997) é exclusiva para narrativas pessoais, como já se disse anteriormente, daí a existência desse paradoxo. No caso de outras narrativas, essa credibilidade parece ter de estar vinculada ao exagero no evento mais relatável ou não, mas especialmente as características da referencialidade, tal como será tratada por Bruner(1991).

Labov (1997) propõe que a correlação temporal de eventos apresentados e sequências sentenciais tenha de ser complementada por uma teoria própria da causalidade, elaborada pelo enunciador-narrador. Desse ponto de vista de Labov (1997), entende-se que as relações entre causa-consequência são estabelecidas pelos comportamentos previamente determinados e, portanto, previsíveis, atribuídos às personagens (vínculos de estados comportamentais brunerianos). As relações causais propostas formam a coesão entre eventos e orações, determinada especialmente pelo conhecimento partilhado entre o enunciador-narrador e seus interlocutores-ouvintes.

Essas relações causais que vêm acompanhadas do conhecimento partilhado suposto entre enunciador-narrador e interlocutor-ouvinte são suplementadas pela definição de funções das personagens como protagonistas e antagonistas. Assim, a todo instante, valendo-se dos mais diferentes recursos linguísticos disponíveis e conhecidos, o enunciador-narrador vai atribuir valores bons ou maus às suas personagens e a seus comportamentos.

A se retomar o princípio de que a narrativa pessoal restringe-se à descrição dos eventos efetivamente vividos pelo enunciador-narrador 
e o princípio de que o interlocutor-ouvinte tem de acreditar nisso, à correlação perfeita entre a ordem cronológica estrita dos eventos apresentados e a sequência sentencial tem de se acrescentar ainda o fato de que a descrição dos eventos deve se dar especialmente da maneira como foram apreendidos pelo enunciador-narrador no momento em que ele os vivenciou. Trata-se de um ponto de vista exclusivo na medida em que somente foi experimentado pelo próprio enunciador-narrador. Todos os demais pontos de vista têm de ser excluídos da narrativa, na medida em que não foram experimentados pelo enunciador-narrador, e acarretariam a perda da credibilidade e a consequência negativa à reatribuição de turno.

Da mesma maneira, todas as descrições que apresentem fatos que não foram apreendidos pelos sentidos do enunciador-narrador naquele preciso momento, mas que possam ter sido objeto de reflexão posterior, ou que possam ter sido descritos por terceiros depois da apreensão dos fatos experimentados pelo enunciador-narrador, acarretariam a mesma perda de credibilidade, porque denunciam que nem tudo ali foi experiência pessoal do enunciador-narrador. Dessa maneira, a narrativa terá maior credibilidade quanto mais descritiva for dos eventos que apresentar. As interferências do enunciador-narrador no sentido de conduzir a interpretação dos fatos pelos interlocutoresouvintes, por meio da inserção de reflexões ou da explicitação das intenções ou das emoções das personagens, atuam, segundo Labov (1997), no sentido oposto do aumento da credibilidade.

Podemos verificar esses fatos, numa pequena narrativa, tal como a que vai abaixo, que foi coletada na zona rural de Taubaté, SP, durante a realização do projeto Filologia Bandeirante (MEGALE, 2000).

Tava meu sobrinho na escola, né? Daí, "Ô, tio, corra aqui, ó uma cobrinha aqui no buraco". Mas eu pensei que era uma cobrinha, né? Fui cum pedacinho de pau. Eu disse "essa cobrinha eu mato cum pedacinho de pau". Cheguei lá, eu... dois cascavel dessa grossura! Que o bicho tava co suizo desse tamanho! Ah! Voltei correndo de lá, catei a cavadeira... Tava no buraco, num tinha jeito de dá paulada. Ca cavadeira soquei o negócio naquele rolo. Assim, né? Já espremi a cabeça dela, com a cavadeira. Segurei, né? Já quebrei ela pro meio. Acabou de cair na estrada. Acabei de matar. Má! Doi chorição dessa compridura. Ele disse "cobrinha, corra aqui matar cobrinha!". 
A ordem cronológica das sentenças dessa narrativa segue exatamente a ordem cronológica em que ocorreram os eventos apresentados. Se as dispusermos em coluna por sentenças numeradas, a visualização será mais fácil:

1. Tava meu sobrinho na escola, né?

2. Daí, "Ô, tio, corra aqui, ó uma cobrinha aqui no buraco".

3. Mas eu pensei que era uma cobrinha, né?

4. Fui cum pedacinho de pau.

5. Eu disse "essa cobrinha eu mato cum pedacinho de pau".

6. Cheguei lá, eu... dois cascavel dessa grossura!

7. Que o bicho tava co guizo desse tamanho!

8. Ah! Voltei correndo de lá, catei a cavadeira...

9. Tava no buraco, num tinha jeito de dá paulada.

10. Ca cavadeira soquei o negócio naquele rolo.

11. Assim, né?

12. Já espremi a cabeça dela, com a cavadeira.

13. Segurei, né?

14. Já quebrei ela pro meio.

15. Acabou de cair na estrada.

16. Acabei de matar.

17. Má! Doi chorição dessa compridura.

18. Ele disse "cobrinha, corra aqui matar cobrinha!"

A narrativa inicia-se com uma sentença restritiva que tem juntura temporal com a sentença 2. Essa juntura tanto vai marcada pela presença de um item lexical — "daî" — como pelo próprio encadeamento. Ainda que seja possível imaginar essa sentença inicial como uma sentença livre, seu encadeamento temporal é suposto, na medida em que faz parte do conhecimento partilhado o fato de que as crianças em idade escolar, naquela zona rural, frequentemente voltam a pé para a casa. Da mesma maneira, o encadeamento temporal entre 
as sentenças 6 e 8 não vai claramente explicitado na narrativa, deixando por conta da interpretação do interlocutor estabelecer as relações necessárias entre o momento em que o enunciador-narrador descreve seu equívoco em relação aos instrumentos selecionados e o tamanho das cobras e seu retorno à casa, a fim de substituir o pauzinho pela cavadeira.

A sentença 2, bem como as sentenças 4, 6, 8, 10, 12, 14-16, formam uma sentença narrativa, enquanto que as sentenças 3, 5, 7, 9, $11,13,17-18$ podem ser caracterizadas como sentenças livres, na medida em que não têm juntura temporal com nenhuma sentença da narrativa.

Se retomássemos exclusivamente as sentenças que têm juntura temporal, teríamos:

Tava meu sobrinho na escola, né? Daí, "Ô, tio, corra aqui, ó uma cobrinha aqui no buraco”. Fui cum pedacinho de pau. Cheguei lá, eu... dois cascavel dessa grossura! Ah! Voltei correndo de lá, catei a cavadeira... Ca cavadeira soquei o negócio naquele rolo. Já espremi a cabeça dela, com a cavadeira. Já quebrei ela pro meio. Acabou de cair na estrada. Acabei de matar.

As sentenças livres, apesar de receberem esse nome, têm completa dependência do contexto narrativo expresso pela sentença narrativa.

3. Mas eu pensei que era uma cobrinha, né?

5. Eu disse "essa cobrinha eu mato cum pedacinho de pau".

7. Que o bicho tava co guizo desse tamanho!

9. Tava no buraco, num tinha jeito de dá paulada.

11. Assim, né?

13. Segurei, né?

17. Má! Doi chorição dessa compridura.

18. Ele disse "cobrinha, corra aqui matar cobrinha!" 
Essas sentenças participam da descrição dos eventos narrados, complementando a cena, como pano de fundo. São, na sua grande maioria, sentenças de conteúdo descritivo. Mas também pode haver sentenças avaliadoras, tal como é possível verificar nas sentenças $17 \mathrm{e}$ 18, em que o enunciador-narrador apresenta sua posição a respeito da interpretação do tamanho fora do normal das cobras e da subavaliação em relação a esse tamanho feita por seu sobrinho.

O evento mais relatável dessa narrativa é obviamente o fato de conseguir matar as cobras, ainda que fique meio confuso, na narrativa, se se trata, de fato, de mais de uma cobra. As sentenças complicadoras apontam sempre para esse fato, que vai se resolver somente na sentença 16, quando termina o escopo da sentença narrativa. De maneira geral, após a "cena" da matança, a narrativa não tem mais condições de sustentar a atenção dos interlocutores.

Um outro exemplo pode contribuir com alguns outros detalhes.

No trabalho desenvolvido por Vera Lúcia Pereira, no Vale do Jequitinhonha, em Minas Gerais

Versão que tenta ser fiel à oralidade:

Chegô nua istrada. $\bigcirc$ sol tava muito quente. Aí tinha ua arvre muito grande, muita sombra. Aí chegô e disarriô o cavalo, sortô o cavalo, ficô chorano ali e foi comê a matula. Imbaxo da sombra tinha ua água passano. Quando ele sentô e tava cumeno, vei um passarim e cantô muito bunito e sentô na arvre do pau e foi... e pegô cantano, cantano, ele foi, incantô cum passarim e falô assim:

- Mais que pássaro mais bunito aquele! Que coisa! Que buniteza!

Aí o passarim foi cantano e pegô a dispená, né? coçano. Naquilo soltô uma pena e ês pássaro vuô. Ele foi no sintido da pena e a pena vuô e caiu perto dele. Aí ele pegô a pena, e, nele pegá a pena, o cavalo falô cum el'assim:

- Num panha essa pena, que tudo com pena será pena. (...) (id. ib., p. 92) (1996), há a transcrição de algumas narrativas que servem para ilustrar essa diferença. A autora transcreveu as narrativas procurando ser, na medida do possível, fiel ao uso oral da língua e, em seguida, tentando adaptar outra ao que a autora chama de "português padrão". Vão abaixo dois pequenos trechos dessas narrativas:

Embora muitas diferenças possam ser observadas, está claro que se trata de dois trechos semelhantes de uma mesma história. A diferença mais ostensiva entre elas está 
justamente no uso da língua. No primeiro trecho, a coesão entre as orações faz-se por meio da sequenciação de frases descritivas. O ouvinte(/ leitor) é levado a imaginar simplesmente as imagens e, delas, extrair os sentidos e as emoções que seriam adequadas àquelas personagens. No segundo trecho, inserem-se mecanismos de coesão linguística como conectivos e correspondências de aspecto e tempo verbais. As variações emocionais das personagens são efetivamente descritas: "cansado e faminto", "sentindo-se só", "extasiado", "sem hesitar" e até uma pena que cai "delicadamente".

Uma das diferenças entre ambas as passagens reporta-se ao que Labov (1997) chamou à atenção quanto às relações causais que formam a coesão entre eventos e orações, determinada especialmente pelo conhecimento partilhado entre o enunciador-narrador e seus interlocutores-ouvintes. A referência ao calor do sol prescinde da referência ao calor da personagem; assim como a descrição do ato de comer prescinde da referência à fome; a referência ao choro da personagem pressupõe sua tristeza sem necessidade de justificá-la; a referência à queda de uma pena igualmente prescinde da descrição de seus movimentos: pessoas choram por tristeza, têm calor porque o sol é forte, comem porque estão com fome, e caem na maneira conforme seu peso e dimensão. São fatos obviamente relacionados ao contexto que exigem a participação dos ouvintes(/leitores) na recuperação das informações dadas no texto ouvido(/lido). A explicitação dos pressupostos no segundo trecho atua no sentido de separar o ouvinte(/leitor) do contexto

Versão em português padrão:

Depois de viajar longo tempo sob um sol escaldante, ele avistou uma árvore frondosa $e$ um belo riacho. Cansado e faminto, desceu do cavalo e sentou-se à beira do riacho, a fim de comer o lanche que seu pai the havia preparado. Então, sentindo-se muito só, começou a chorar até que ouviu um lindo canto: um pássaro havia pousado num dos galhos da árvore, e cantava ininterruptamente. Extasiado, o rapaz começou a cantar também, sempre observando a ave, que cantava e se coçava.

Nesse momento, uma pena do pássaro se soltou e voejou delicadamente até pousar sobre os pés do rapaz, que a apanhou sem hesitar. Em seguida a ave voou. Ao ver aquilo, o cavalo disse:

- Não pegue essa pena, que tudo com pena será pena! (id. ib., p. 98) 
fictício da narrativa, como a eliminar a familiaridade dos comportamentos e exigir outra forma de interpretação senão aquela óbvia que se pode extrair do primeiro trecho. Dessa maneira, a informação dada teria de ser interpretada como nova, o que impossibilitaria a compreensão do texto. É a tecnologia da escrita que muda isso. Ao leitor letrado tudo se faz óbvio, ao leitor neófito é possível que o mesmo não ocorra. Na medida em que não se pode atribuir sentidos a sentidos já atribuídos, não há o que interpretar, exigindo do ouvinte(/leitor) o desenvolvimento de novas estratégias para a atribuição de sentidos.

\section{A transformação da narrativa}

A ideia de que a memória é um fenômeno cognitivo dependente de sua exteriorização na forma de alguma das linguagens disponíveis suscita a necessidade de um veículo próprio para isso. Conforme já lembramos, a própria língua é a que melhor propicia a sua exteriorização. No entanto, sua exteriorização dá-se de maneira bastante particular, como já vimos a partir da interpretação das ideias de Halbwachs (1990) e de Labov (1997), por meio do desenvolvimento de narrativas que se desenrolam seja como narrativas pessoais seja como narrativas coletivas. $\mathrm{O}$ que se deve salientar, por sua vez, ainda retomando as ideias de Halbwachs (1990), é que as narrativas são atos de enunciação que se desenvolvem sempre no presente, apesar de suas referências específicas ao passado recente ou ao passado remoto, que devem ter o poder de coerção necessário ao convencimento do interlocutor que pode ser inclusive o próprio enunciador, e que, para tanto, precisam estar constantemente atualizadas.

Muito embora não esteja relacionando a narrativa com a memória propriamente dita, Bruner (1991) propôs que o pensamento narrativo opera como um instrumento mental de construção de realidade. Para tanto, ele estabeleceu 10 características, quais sejam: 1) diacronicidade narrativa; 2) particularidade; 3) vínculos de estados emocionais; 4) 
composicionalidade hermenêutica; 5) canonicidade e violação; 6) referencialidade; 7) genericidade; 8) normatividade; 9) sensibilidade de contexto e negociabilidade e 10. acréscimo narrativo.

Nesse conjunto de dez características, podemos estabelecer dois grupos grosseiramente organizados: características de nível alto e características de nível baixo. Ambos os grupos atuariam diretamente na formação das narrativas, sendo imprescindíveis para a sua manutenção. Cada um deles, entretanto, lida com um aspecto bastante diferenciado da narrativa. As características de nível baixo atuam de forma concreta, diretamente sobre os elementos da narrativa e sobre fatos próprios da enunciação e de suas referências (token, bottom-up, indução), e características de nível alto são referências subjetivas que atuam indiretamente sobre a realidade (type, top-down, dedução). Podemos dividir as características nesses dois grupos como vai a seguir:
A) Características de nível baixo:
B) Características de nível alto:
2) particularidades
1) diacronicidade narrativa;
6) referencialidade;
3) vínculos de estados emocionais;
7) genericidade;
4) composicionalidade hermenêutica;
9) sensibilidade ao contexto e negociabilidade;
5) canonicidade e violação;
10) acréscimo narrativo.
8) normatividade.

Bruner (1991) descreve o acréscimo narrativo como a "capacidade 'local' para acrescentar histórias de acontecimentos passados a algum tipo de estrutura diacrônica que permita uma continuidade até o presente - em resumo, construir uma história, uma tradição, um sistema legal que assegurem continuidade histórica, senão legitimidade”. (p. 19-20, tradução minha) Desse ponto de vista, o acréscimo narrativo é a própria justificativa para a sua existência ou para sua ocorrência na enunciação. Uma narrativa, por exemplo, poderá estar encaixada como uma das peças de uma atividade ritualística, seja religiosa ou não, de maneira a dar o fundamento para a própria atividade ou mesmo para servir de suporte 
de conhecimentos para diagnóstico ou cura. Nos casos mais corriqueiros da nossa atualidade, justificam-se as narrativas pelos seus propósitos de identificação social, quer seja por meio da autoglorificação quer seja pela estigmatização do outro. As ocorrências das narrativas variam enormemente quanto às suas necessidades desencadeadoras. No entanto, elas parecem atuar sempre no sentido de criar coesão e coerência sociais, mesmo que isso possa não ser muito claramente percebido.

Observando alguns exemplos, podemos entender melhor.

Após a leitura das três narrati-vas (quadro ao lado), a pergunta mais interessante que se pode fazer, em relação às proposições feitas por Labov (1997), quando chamou a atenção para o fato de que os temas preferidos para as narrativas são sexo, morte e questões morais, é justamente quanto à qual dos três as narrativas se referem. Tais temas formam por si sós as justificativas para a ocorrência das narrativas. Obviamente, nesse caso, entende-se tratar-se de questões morais. Todas as narrativas envolvem uma questão comportamental repreensível, com penalização evidenciada na própria narrativa. Por se tratar da fuga da Virgem Maria, num caso, da Virgem

"O bem-te-vi é ave amaldiçoada, porque com seus gritos, 'bem-te-vi', ele ia mostrando pros soldados os lugares por onde a Virgem Maria passava, no tempo que precisou fugir de sua terra." (XEDIEH, 1993, p. 32)

"A corruíra e a galinha são aves amaldiçoadas porque quando a Virgem fugia para o Egito e São José ia atrás jogando gravetos por cima dos rastros do burrinho, aquelas duas vinham ciscar o graveto e, por ruindade, mostrar aos soldados o rumo que a família ia tomando." (XEDIEH, 1993, p. 34)

"O porco foi amaldiçoado porque quando a Sagrada Família ia fugindo, ele vinha atrás e fuçava os gravetos que São José tinha jogado em cima dos rastos do burrinho, mostrando o caminho pros soldados de Herodes." (XEDIEH, 1993, p. 34)
Maria e de São José no outro e da Sagrada Família no terceiro, pode-se entender tratar-se de uma narrativa de cunho religioso e, portanto, relativa às questões morais próprias da religião que tem esses personagens. Certamente as ações referentes à fuga e ao destino dessas personagens fazem parte do conjunto de conhecimentos compartilhados pela comunidade da qual se extraiu essa narrativa. $\mathrm{O}$ acréscimo narrativo desse ponto de vista associa uma história do passado remoto, quando houve uma maldição 
lançada a alguns personagens, que ainda hoje existem, à necessidade de salientar o exemplo comportamental da denúncia efetivamente penalizada por uma instância sobrenatural, como no caso da história.

Do ponto de vista da coesão social, está claro que os narradores entendem-se como descendentes ou seguidores dos que foram delatados e dos amaldiçoadores e não dos delatores e dos perseguidores. A estigmatização das personagens atua, nesse caso, como o elemento formador da comunidade que faz essa narrativa, ou seja, para ser tratado como membro da comunidade, há que se avaliar como negativas as atitudes do sabiá, do curruíra, da galinha, do porco e dos soldados, e como positivas as atitudes da Virgem Maria, de São José, da Sagrada Família e do Amaldiçoador.

Entram no conjunto das particularidades todos os elementos que são próprios da interpretação literária, tais como personagens, lugar e todos os demais elementos do cenário em que a narrativa se desenvolve. Especificamente, as particularidades são o meio (mídia), no sentido mcluhaniano, que suporta a narrativa. $\mathrm{O}$ meio, nesse caso, está fortemente associado à referencialidade, na medida em que ela é a fonte contextual de que se extrairão as particularidades. As variações no contexto estabelecem a necessidade de transformações das particularidades. Podem-se tomar as particularidades como o léxico próprio da narrativa, todo o elenco de personagens, de roupagens, de locais, dentre todas as outras possibilidades, selecionadas no conjunto de uma época específica. Associando essa característica ao que já vimos anteriormente, as particularidades devem ser extraídas de um contexto específico diretamente associado às referências pessoais do passado recente do enunciador, se se tratar de uma narrativa pessoal, ou às referências coletivas do passado remoto da sociedade, se se tratar de uma narrativa mítica ou histórica. Assim, o conjunto das particularidades deve restringir-se a um contexto bastante específico conforme as referências sejam pessoais ou coletivas. A decisão deve ser tomada especialmente pelo propósito da enunciação. Assim, os motivos 
que desencadearam a narrativa, sejam eles relativos à religião, ao entretenimento, às práticas educativas ou outros quaisquer, acrescentam à narrativa as necessidades referenciais próprias daquele momento.

Ainda em relação às três narrativas tomadas de Xedieh (1993), podemos estabelecer algumas particularidades:

$\begin{array}{lll}\text { Narrativa 1 } & \text { Narrativa 2 } & \text { Narrativa 3 } \\ \text { Bem-te-vi } & \text { Corruíra e Galinha } & \text { Porco } \\ \text { Virgem Maria } & \text { Virgem Maria e São José } & \text { Sagrada Família } \\ \text { Soldados } & \text { Soldados } & \text { Soldados } \\ \text { Amaldiçoador } & \text { Amaldiçoador } & \text { Amaldiçoador } \\ \text { com os gritos mostrava } & \text { ciscavam o gravetos e } & \text { fuçava os gravetos } \\ \text { os lugares para os } & \text { mostravam aos soldados } & \text { mostrando o caminho } \\ \text { soldados } & \text { o rumo } & \text { para os soldados } \\ \text { fuga de sua terra } & \text { fuga para o Egito } & \text { fuga }\end{array}$

Nas três narrativas acima, podem-se notar alguns exemplos muito evidentes das particularidades propostas por Bruner (1991). Podem ser referentes às personagens, como Bem-te-vi, Porco, Soldados, Amaldiçoador, ou a ações como a fuga e a denúncia aos soldados. Há manutenção, como no caso do Amaldiçoador, que não vai explícito no texto, ou dos soldados, que, neste caso, vai explícito, ou da fuga, ou do fato da denúncia. Mas, neste último caso da denúncia, podem-se discriminar as particularidades das formas de denúncia, devidamente adaptadas às demais particularidades: o bem-te-vi grita, a galinha e o corruíra ciscam e o porco fuça.

Quanto à referencialidade, deve-se salientar o fato de que as particularidades foram escolhidas de forma a estabelecer a coerência entre o fato narrado e a comunidade que faz a narrativa. A seleção de animais distintos dos familiarmente conhecidos eliminaria a coerência narrativa com a própria comunidade. Quaisquer animais poderiam 
ter sido escolhidos para atuarem como delatores, fossem eles zebras, ornitorrincos, cangurus ou ursos polares. A seleção que se fez pautouse na presença dos animais no contexto da comunidade; bem poderiam ter sido gatos, gambás, morcegos ou outros, desde que se adaptassem suas formas de denúncia.

Como se viu, a ausência de correlação entre essas variáveis quais sejam: acréscimo narrativo, referencialidade e particularidades - acarretaria a dissociação entre contexto e narrativa grosseiramente, a descontextualização da narrativa - e a sua consequente folclorização. ${ }^{13}$ Nesse caso, a característica "sensibilidade ao contexto e negociabilidade" apresenta-se como a mais intimamente relacionada à característica "acréscimo narrativo", na medida em que os interlocutores-ouvintes devem estar seguros não só da justificativa para a ocorrência da narrativa, como também da certeza de que vai atingir o objetivo proposto. Salienta-se que a sensibilidade ao contexto relaciona essa apropriação do interlocutor-ouvinte com a própria elaboração da narrativa, tomando o meio como ele próprio, para atribuirlhe por si só significado. A percepção mais forte das características de nível baixo torna-se uma espécie de ruído que impossibilita a narrativa na forma como vai proposta pelo narrador. Essa característica, no caso das narrativas orais, associa-se diretamente à necessidade que Labov (1997) salientou de reatribuição de turno feita pelos interlocutoresouvintes ao falante-narrador. A "relatabilidade" proposta por Labov (1997) atua como essa característica do acréscimo narrativo bruneriano. As justificativas para a ocorrência de uma narrativa oral, não

13 Desse ponto de vista, é oportuna a consideração de Câmara Cascudo, feita em 1949: “O folclórico decorre da memória coletiva, indistinta e contínua. Deverá ser sempre o popular e mais uma sobrevivência. O popular moderno, canção de Carnaval, anedota de papagaio com intenção satírica, novo passo numa dança conhecida, tornar-se-ão folclóricos quando perderem as tonalidades da época de sua criação.

Assim um poema, um trecho de História que a simpatia popular divulgou, a música de uma canção, nacional pela memória coletiva, marcham para a despersonalização que as perpetuará no Folclore." (CASCUDO, 2006. p. 23) 
necessariamente pessoal, podem variar em função das necessidades sociais. No caso das narrativas religiosas ou ritualísticas, ou das narrativas propostas para fins especialmente didáticos, por exemplo, as justificativas decorrem de uma necessidade social imediata externa ao domínio da enunciação pelos interlocutores envolvidos.

Novamente retomando as três narrativas tomadas de Xedieh (1993), podemos observar que o contexto religioso, além de cristão, atenta, por exemplo, para a sacralização da Virgem Maria e de São José. Pode-se facilmente imaginar situações em que tal narrativa precise receber as transformações necessárias para ser aceita pelos interlocutores. É o bastante questionar a existência de santos para que todas as três narrativas sejam inapropriadas. Nesse caso, seria necessária uma adaptação das particularidades referentes a essas personagens. Essa é uma responsabilidade que cabe exclusivamente ao narrador, no momento da elocução e, portanto, é a característica de sensibilidade ao contexto e negociabilidade.

Apesar de estarmos propondo que essas características estejam diretamente relacionadas aos aspectos materiais da narrativa, o acréscimo narrativo é o que mais se aproxima das características de nível alto. Por se tratar de uma característica que envolve a motivação da própria narrativa, entendemos que deve ser tomada como parte externa do processo de narração. Muito provavelmente essa característica tem a ver com o próprio processo de criação dos mitos explicativos, mesmo o da origem, a formação da religião, da ciência, da história, na medida em que se mostram como a criação de uma memória que explique e justifique as características do presente. As narrativas que declaram origens de maneira geral, sejam da população, da família, de algum comportamento ou de algum objeto, ainda que não precisem decorrer da criação de histórias, mas tão-somente da transformação das narrativas preexistentes em narrativas míticas, assumem, junto com as demais características, valor de verdade. A cristalização dessas narrativas, por sua vez, atua muito proximamente à característica da "composicio- 
nalidade hermenêutica" no aspecto da "banalização narrativa" e pode, portanto, ser tomada de forma ritualística.

Finalizando as características de nível baixo, a genericidade é a de que convém tratar, uma vez que está diretamente relacionada à seleção do gênero textual escolhido para a narrativa, conforme se verá mais adiante, quando tratarmos das propostas de Vansina (1982). Ao classificar as "formas fundamentais da tradição oral", o autor estabelece quatro categorias - poema, fórmula, epopeia e narrativa distribuídas da seguinte maneira:

\begin{tabular}{|c|c|c|c|}
\hline \multirow{4}{*}{} & \multicolumn{3}{|c|}{ CONTEÚDO } \\
\cline { 2 - 4 } & & fixo & $\begin{array}{c}\text { livre escolba } \\
\text { de palavras }\end{array}$ \\
\cline { 2 - 4 } & estabelecida & poema & epopéia \\
\cline { 2 - 4 } & livre & fórmula & narrativa \\
\hline
\end{tabular}

Essa classificação proposta por Vansina (1982) estabelece restrições específicas para cada uma das formas de narrativa. Ao optar por narrativas de conteúdo fixo e forma estabelecida, o autor se sujeita à manutenção da narrativa tal como tomou conhecimento dela. Nesse caso específico, pode-se imaginar a ausência das mudanças. Atualmente é possível encontrar essas narrativas na forma de orações religiosas, por exemplo, em que um grupo pode fazer a narrativa simultaneamente. Pode-se pensar tratar-se de uma consequência da documentação escrita, que nos permite manter a muito longo prazo uma forma e um conteúdo imutáveis. No entanto, há que convir que a presença constante de rituais com orações perfeitamente idênticas num contexto iletrado, sobretudo em comunidades em que há a predominância de analfabetos, permite-nos tratar de fato, no mínimo, como reminiscência da Tradição Oral em nossa sociedade. Mas encontram-se as formas estabelecidas de conteúdo fixo de maneira muito mais frequente nas comunidades em que há o predomínio quase absoluto da Tradição Oral. Em várias 
sociedades, por exemplo, há a prática de se recitar longas genealogias ininterruptamente, ou então descrever a topografia ou a corografia do território tradicional de um grupo.

As narrativas de forma estabelecida e livre escolha de palavras são, via de regra, caracterizadas pela métrica, pela rima, pela sucessão de partes, dentre outras possibilidades. O cururu rural que era produzido no interior paulista, geralmente acompanhado de dança também improvisada (ARAÚJO, 1973), e os repentes produzidos no nordeste brasileiro são exemplos bastante interessantes. Atualmente, é possível encontrar no canto rap, em diversas regiões, exemplos característicos da manutenção da forma estabelecida com a variação livre das palavras utilizadas. Não se vá confundir as manifestações improvisadas dos rappers com as gravações de músicas semelhantes.

Formas livres e de conteúdo fixo são as mais difíceis de se localizar. Entendemos que piadas, adivinhas, ditos, frases feitas, metáforas cristalizadas caracterizam bem esse tipo de tradição.

Ao contrário do caso anterior, as narrativas com forma livre e com livre escolha de palavras são as que mostram maior difusão. Espalham-se por todos os lados, reproduzidas diretamente às crianças, aos adultos. Subdividem-se facilmente em inúmeros outros gêneros narrativos, tal como as lendas, os casos, os contos o quais são exemplos notáveis dessas narrativas.

No que diz respeito às características de nível alto, entendemos tratar-se de fenômenos subjetivos que se compõem a partir dos de nível baixo, e são gerados a partir da existência da própria narrativa. Embora a diacronicidade possa ser tomada como um fenômeno externo, Bruner (1991) salienta que o tempo é um tempo subjetivo, que não se sujeita às vicissitudes da temporalidade real. Desse ponto de vista, entendemos que o autor proponha que a narrativa, bem como a música, ou a direção espacial, manifeste-se numa só dimensão, tratando-se de um fenômeno linear. As variações dessa linearidade seriam "sofisti- 
cações" da linearidade do fenômeno. A complementação dessa diacronicidade com a noção de juntura temporal proposta por Labov (1997) evidencia a necessidade de se usar dos recursos de uma linguagem adaptada às necessidades da narrativa, isto é, que disponha de marcadores temporais adequados para distinguir presente, passado recente e passado remoto. A sequência "sentença restritiva $\rightarrow$ sentença complicadora $\rightarrow$ coda" do esquema laboviano vai ao encontro da diacronicidade proposta por Bruner (1991) para a narrativa.

A "composicionalidade hermenêutica" é o ponto em que a narrativa textual assemelha-se à narrativa melódica. Trata-se da interpretação gestáltica de uma sequência de eventos - que não estão necessariamente conectados entre si - como se estivessem conectados, formando uma sequência de causas e consequências inesperadas (desconforto) que deverá levar a uma finalização que é a consequência esperada (satisfação). Labov (1997) chamou a atenção também para o fato de que a narrativa deve ter uma teoria da causalidade elaborada pelo enunciador e pelo interlocutor-ouvinte. Dessa maneira, a sequência de eventos se transforma quando as mudanças que transformam o mesmo em outro, quando os costumes com os quais estamos familiarizados provocam consequências inesperadas; tudo isso gera ou a necessidade do retorno ao ponto inicial que se perdera ou então o seu abandono completo pela formação de uma nova identidade, com nova familiarização de costumes. No entanto, a percepção do conjunto, quer o que promova o retorno, quer o que promova a mudança, dá-se tãosomente por um processo previamente estabelecido de que a sequência dos fatos tem de ser tomada como um fenômeno naturalmente encadeado - "diacronicidade" — e pronto a formar constantemente um todo coerente e coeso, que sirva como referência para as novas variações aleatórias, ou para as variações de suspense com retorno triunfal ao mesmo ponto.

O princípio básico que rege a variação nas narrativas é o que será chamado mais adiante por Bruner (1991) de "normatividade" e o 
que promove a sua fuga será o da "canonicidade e violação". A complementaridade desses processos é notável, assim como a percepção da quebra também o é. De fato, a quebra da norma, pela variação excessiva, exige que o indivíduo cujos sentimentos são o medo e a frustração crie em si próprio a necessidade de retorno ao ponto inicial, com o qual estava familiarizado, em que sentia segurança e conforto. Mas, ao mesmo tempo, a sensação da fuga e da aventura é agradável e estimulante. A aventura se caracteriza pela esperança — "vínculos de estados emocionais" - de se voltar ao ponto inicial, retomando a "normatividade" perdida. A esperança dessa volta, isto é, a lembrança dos momentos de conforto e de segurança bem como a expectativa de seu retorno garantem a identidade do indivíduo - é a "composicionalidade hermenêutica" - , em que pese o fato de ela estar ameaçada pelas variações significativas que podem não levar ao conforto e à segurança da "normatividade".

A "composicionalidade hermenêutica", portanto, é um efeito direto das características de "normatividade", "canonicidade e violação", "diacronicidade" e "vínculos de estados emocionais". Se a proposta é a de que essa "composicionalidade hermenêutica" é a manutenção da identidade, teremos que a manutenção da identidade é também um efeito destas características: sequências de normas, violações e retornos a um estado inicial/fundamental (novo ou não), isto é, uma sequência de emoções de segurança e conforto devida à "normatividade", seguida de medo e frustração devida à "canonicidade e violação", com estimulação agradável, ou satisfação, da fuga assegurada de retorno (a aventura) devida a "vínculos de estados emocionais".

As diferenças entre a música e a narrativa estarão presentes nas características de nível baixo propostas por Bruner (1991): "particularidade", "referencialidade", "genericidade", "sensibilidade ao contexto e negociabilidade", "acréscimo narrativo”. Essas diferenças, entretanto, não interferem, de maneira geral, no desenvolvimento da narrativa, que se caracteriza basicamente pelas demais. O que ocorre nesse caso é 
a adequação da narrativa às necessidades específicas de um grupo ou de um indivíduo. Eventualmente, é possível que mudanças mais radicais nas particularidades percam a força relativa aos demais acontecimentos básicos e, de certa maneira, não possam mais garantir, por exemplo, uma sequência de normatividade e de canonicidade e violação, e, portanto, do conforto ao desconforto. Nesse caso, os suportes/ meios tratam de promover a supressão ou a transformação nos demais elementos da narrativa, particularmente no que diz respeito à "normatividade" e à "canonicidade e violação".

No entanto, na medida em que emoções não aparecem no vazio, é fundamental que a inversão dos processos seja estabelecida. As características de suporte da narrativa são efetivamente as que estabelecem as reações emocionais. Trata-se, obviamente, da simulação de fatos que poderiam estar se desenrolando. Não se podem provocar emoções se as violações da norma não forem realizadas por indivíduos específicos e se essas normas não se manifestarem por meio do comportamento desses indivíduos. Em que pese não serem fundamentais para a narrativa, as particularidades são imprescindíveis na medida em que são o próprio meio da narrativa.

As particularidades são selecionadas valendo-se dos critérios propostos. Nesse caso particular, as características de "particularidade" e "referencialidade" são as que têm importância como suporte para a existência da narrativa. Assim, apesar de essas características lidarem com fatos com grande facilidade para transformação, não são prescindíveis para a existência da narrativa com suas características básicas.

A "sedução narrativa" parece associar-se com o domínio do código, ou a reprodução bastante eficaz dos índices de "verdade" que a narrativa em foco produz. A distinção entre o que é verossímil e o que é verdadeiro atinge, nesse caso, a menor variação possível. Trata-se, portanto, de uma aproximação com a característica da "referencialidade" tal como foi proposta. Não há, necessariamente, que se definir um type (um fenômeno genérico), mas, facilmente, pode ser definido um token 
(um fenômeno específico, para usar a terminologia do autor). A transformação de types em tokens permite exatamente a confusão entre o verossímil e o verdadeiro. Trata-se precisamente da variação entre a mentira e a ficção. A interpretação feita pelo ouvinte, num caso como esse, não lhe permite retomar o fenômeno senão como um acontecimento que de fato ocorreu.

Um outro aspecto na própria "sedução narrativa" é justamente atar-se à noção de estilo. De fato, o estilo também atua na forma de domínio do código, aproximando o verossimilhante do verdadeiro. Mas, também, atua no sentido de gerar constantemente desejos de satisfação por meio da elaboração de falsos caminhos ou de falsas resoluções. Trata-se, também, de um procedimento bastante semelhante ao das modulações melódicas, em que uma resolução no fundamental é preterida pelas falsas resoluções em outros tons, provocando assim um efeito de suspense e, portanto, de insatisfação.

A "sedução narrativa" é justamente o mecanismo de que se valem os melhores narradores, ou contadores de história, quer sejam autores ou intérpretes das narrativas que produzem. Alguns mecanismos para essa "sedução narrativa" são consagrados e facilmente reprodutíveis, especialmente quando lidam com desejos de satisfação relacionados a sexo, tristeza, frustração, medo ou coisas que tais.

Podemos exemplificar essas características, a partir da primeira das três narrativas extraídas de Xedieh (1993) que usamos mais acima e que ora reproduzimos aqui, com suas sentenças dispostas em coluna.

1. O bem-te-vi é ave amaldiçoada,

2. porque, com seus gritos, 'bem-te-vi', ele ia mostrando pros soldados

3. os lugares por onde a Virgem Maria passava,

4. no tempo que precisou fugir de sua terra. 
$\mathrm{Na}$ medida em que estamos a imaginar que narrativas como essa ocorrem especialmente na oralidade, como parte da Tradição Oral, é possível pensarmos que podem sujeitar-se às mesmas formas de análise e descrição dos diálogos, ainda que algumas diferenças tenham de ser postuladas. Tais diferenças foram expostas na descrição de Labov (1997), que se apresentou mais acima.

Grice (1982) postula a existência de um princípio chamado "de cooperação". Ele lembra que os participantes de um diálogo não entendem que uma conversa consista em uma sucessão de observações desconectadas; mas, ao contrário disso, eles reconhecem um propósito comum ou um conjunto de propósitos, ou, no mínimo, uma direção mutuamente aceita. ${ }^{14}$ Desse ponto de vista, imagina-se que os interlocutores-ouvintes estarão dispostos a atribuir sentido à sequência de sentenças apresentadas. De maneira semelhante à proposta de Labov (1997), podemos imaginar que os interlocutores-ouvintes entendem que se trata de uma sentença narrativa, que se inicia por uma sentença livre, que é seguida por uma sentença restritiva que estabelece juntura temporal com as demais e que serve como explicação para a primeira sentença livre. Apesar de essa relação estar marcada pela conjunção "porque”, essa conjunção é dispensável.

De maneira mais geral, pode-se dizer que a enunciação, na forma como foi proposta por Benveniste (1989), é um acordo estabelecido pelos participantes em que o enunciador-narrador propõe que o texto enunciado tenha um sentido e o seu interlocutor o aceita, procurando interpretá-lo tal como foi proposto. Tanto do ponto de vista de Grice (1982) como de Benveniste (1989), a narrativa recebe na sua própria enunciação um fio condutor que gera uma unidade coerente e plena de sentido, cujo desenvolvimento vai decorrer das técnicas próprias para isso. Assim, mesmo as narrativas cuja sequência não manifeste

${ }^{14}$ p. 86; cf. KOCH; TRAVAGLIA, 1989 e FIORIN, 2002, para informações mais detalhadas da proposição de Grice. 
um sentido imediatamente perceptível, esse apenas seria apreendido no momento exato de sua enunciação.

Algumas quadrinhas, apresentadas por Melo (1979), podem ilustrar esse aspecto.

Apesar da dificuldade de se estabelecer uma coerência semântica que nos permita encadear as sentenças, é possível considerá-las, em cada quadrinha, como uma

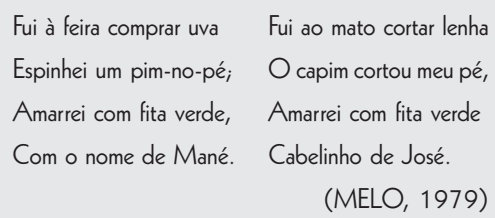
estabelecida e livre escolha de palavras, uma epopeia de Vansina (1982), podemos propor que os elementos coesivos são eminentemente formais e que são eles que orientam a interpretação das sequências como uma sentença narrativa. Vale salientar que todas as características propostas por Bruner (1991) têm de estar sempre presentes nas narrativas.

Relembrando o que disse Câmara Cascudo (2006; cf. nota 8) quando definiu o folclore como a despersonalização ou a perda das tonalidades de época, é possível verificar que as referências usadas nas narrativas para a formação das particularidades não seriam precisamente aquelas que reconheceríamos em nosso dia-a-dia: cortar lenha descalço, por exemplo, é atividade que não faz parte de nosso cotidiano; comprar uvas na feira, provavelmente se fará calçado. Algumas expressões como "espinhei um pim-no-pé" e "cabelinho" igualmente se despersonalizaram, apesar de não serem incompreensíveis, isto é, não há uma interpretação pronta, por conta dos ouvintes-interlocutores para elas. Semelhantemente, a prática amorosa ou sentimental que se propõe nas quadrinhas de se amarrar uma fita verde no pé machucado com o nome de alguém de quem não se deseja esquecer não parece também ser continuada. Apesar da folclorização dessas quadrinhas, não deixamos de atribuir a elas o valor de uma sentença narrativa. 
Diferentemente do anterior, no exemplo abaixo, no fragmento extraído de Pinto (2006, p. 223-4, com adaptações na transcrição), a forma narrativa é livre, bem como a escolha de palavras.

Eu já vi o tal de lubisomem... Eu encontrei com ele. Isso eu era guri, era gurizão. Porque nós ia pro baile - antigamente polícia ia atrás de nós no baile - então eu cheguei numa fazenda... Trabaiava aqui perto de Rio Verde. Aí fui, falei pra mãe:

— Vô pro baile.

- Que cê vai fazê guri?

— Ah! Vô lá, mãe. Vô dá uma olhada no baile. Vô arrumá uma namorada, né? Gosto de dança.

Aí fui pra lá. Aí nós fomos entre lote de gurizada: foi dois irmão meu e um colega nosso. E cheguemo lá. Daí era uma casa de uma muierada lá e não podia ficar de menor de jeito nenhum. Então fica um sondando é tempo de patrulha, né? do quartel, que ela escurraçava nós e a polícia. Aí chegô a patrulha. Nós currimo na casa da dona do baile. Mas nós num conhecia a dona direito. Nós fiquemo escondido embaixo da mesa e a patrulha, fazendo a revista por lá, achou nós lá embaixo da mesa. Ah! Já saiu "pega num pega"... Nós era, naquele tempo, era magrinho, curria. Aí desci, passei um córgo que até chama córgo João Guia. Aí ele não pôde cum nós. Ele não quis molhar a botina dele. Ele me largô ali. Mas ele ia "pega num pega" na coisa da minha camisa. Eu sentia a mão dele passar. Eu falei "se chegá de roda na frente desse homem ele vai..." Aí passei o córgo, ele largou de mim.

Foi logo que tava formando a nova Aquidauana. Num tinha casa nenhuma na chegada daqui pra lá. A senhora conhece ali a nova Aquidauana, né? Num tinha nenhuma... Era até um... Quando ia com boiada, então, saía... Ali, fizeram um boiadeiro. la sair lá na boiaderia mesmo. É. Então, eu... O luar tava claro. Eu extraviei dos companheiro... Falei "Se eu volta pra lá essa turma vai me pegar ainda. Eu vou embora pra casa." Aí, eu ia indo na estrada e, de longe, eu vi. Tava o luar claro. Vi aquele tareco preto que vem vindo. Eu falei "ih::: ai, ai, ai! Já pra trás." Já era uma metade grande pra mim voltar, né? Falei "pra mim vortá pra tráis num dá." Lá vai eu pra frente. Aí, eu parei uma distância. Parei, fiquei meio de joelho, de olhá ele. "Vô vê que bicho que vem vindo aí." E ele veio vindo. "Mas ele é bem feio mesmo. Aquele bicho tá loco." Ele chegou uma distância... Acho que ele nem me viu direito, porque eu tava...

A narrativa no quadro pode ser descrita a partir da caracterização das sentenças narrativas tal como foram apresentadas por Labov (1997). As sentenças livres são aquelas que prescindem da ordem de aparecimento no discurso, que mantêm o seu valor-verdade durante todo o desenvolvimento das ações; as sentenças presas são aquelas que não podem receber nenhum tipo de inversão na ordem de aparecimento no discurso, porque mantêm correlação direta com a ordem de ocorrência das ações descritas; essas sentenças presas pela juntura temporal formam a chamada sentença narrativa e proveem o chamado evento mais relatável que garante o interesse na narrativa, por parte 
dos interlocutores-ouvintes. No caso em questão, o evento mais relatável é o contato com o lobisomem. É o evento que garantiu ao enunciadornarrador o seu direito à atenção dos seus interlocutores-ouvintes. De uma maneira geral, podemos dizer que esse evento mais relatável é o suporte temático da narrativa que se desenvolverá, cabendo ao enunciador-narrador o conhecimento de todos os recursos necessários para sustentá-lo como fato que mantenha o interesse de todos.

Podemos verificar que as particularidades selecionadas pelo enunciador-narrador para compor a sua narrativa foram extraídas do contexto próprio da época e local de sua infância: um baile, um córrego, amigos, polícia, casa de tolerância, botina, boiadeiro... Essas particularidades estabelecem a referencialidade desejada, na medida em que localizam as ações da narrativa em um espaço e num momento bem definidos do passado do enunciador-narrador. A garantia da referencialidade, por exemplo, dá-se no uso de algumas sentenças livres, espalhadas pela narrativa: "Isso eu era guri, era gurizão", "Trabaiava aqui perto de Rio Verde.", "Foi logo que tava formando a nova Aquidauana. Num tinha casa nenhuma na chegada daqui pra lá.", "passei um córgo que até chama córgo João Guia." Essas referências estabelecem parâmetros para a localização no espaço e no tempo. No entanto, há outras que garantem a coerência interna da própria narrativa, de maneira que as particularidades não se dispersem umas das outras. É o caso de justificativas como: "Nós era, naquele tempo, era magrinho, curria", "Eu extraviei dos companheiro...", "O luar tava claro.", "Ele decerto vinha de cabeça baixa, sei lá!”. Essas justificativas, que são sentenças livres, atuam no sentido de garantir que as ações descritas na sentença narrativa sejam aceitas como verdadeiras pelo interlocutoresouvintes.

De certa forma, tanto o conjunto de particularidades quanto as referencialidades atuam em conjunto para a sensibilidade ao contexto e negociabilidade. Dá-se isso em função da necessidade de se manter a atenção dos interlocutores-ouvintes. Ao desencadear uma suspeita de 
que tais fatos não são coerentes entre si, ou de que não poderiam ter ocorrido no local ou no momento em que ocorreram, isso acarretaria a imediata perda do direito ao turno estendido que lhe foi concedido pelos interlocutores-ouvintes e, consequentemente, à interrupção abrupta da narrativa. Pode-se imaginar, portanto, que, se a narrativa continua, então as particularidades e a referencialidade estão sendo cumpridas de acordo com o que requer a sensibilidade ao contexto e negociabilidade.

A possibilidade de variação nas particularidades e na referencialidade vai bem ao encontro do fato de o enunciador-narrador estar formulando seu discurso como uma narrativa livre, que tem forma livre e livre escolha de palavras. $\mathrm{O}$ tema, fortemente preso à tradição das narrativas de lobisomem, entretanto, faz parte de um temário próprio de determinadas culturas. No caso em questão, trata-se da genericidade. De maneira geral, tanto Labov (1997) como Bruner (1991) optam por esse gênero de narrativa para a apresentação de suas propostas teóricas. No entanto, conforme já se lembrou ao tratar das demais possibilidades da Tradição Oral, o mesmo fato poderia ter sido disposto com forma estabelecida ou sem livre escolha de palavras.

Finalmente, nesse grupo de características de nível baixo, podemos discutir o acréscimo narrativo, tentando depreender a motivação da própria narrativa pessoal. Trata-se de uma característica que certamente determina um conjunto de fatos selecionados bem como de sua forma de apresentação, na medida em que a justificativa para se fazer a narrativa perpassa pela expectativa criada pelo próprio enunciador quanto à sua identidade, ou seja, quanto às formas de desempenho que teve em seus papéis sociais assumidos durante sua vida.

Em relação às características de nível alto, a diacronicidade, cuja definição vai ao encontro da noção de juntura temporal de Labov (1997) nas narrativas pessoais, é possível verificar a linearidade temporal, não havendo muito que se discutir a respeito. 
A seleção das emoções atribuídas às personagens, por sua vez, é a característica que vai efetivamente estabelecer se os desempenhos dos papéis sociais estiveram de acordo com o que poderia ser esperado ou não. De maneira mais geral, essa característica vai ao encontro da relação que se estabelece entre as particularidades e a referencialidade. As atribuições de emoções não precisam necessariamente estar expressas literalmente na narrativa. Já dissemos que as interferências do enunciador-narrador conduzindo a interpretação dos interlocutoresouvintes, por meio da explicitação das intenções ou das emoções das personagens, atuam negativamente no desenvolvimento da narrativa. Desse ponto de vista, podemos verificar que o enunciador-narrador na narrativa que estamos analisando não explicita as emoções ou as intenções de suas personagens. Em nenhum momento se afirma que o narrador teve medo da polícia ou do lobisomem, ou que a polícia tinha a intenção de pegar os meninos fujões. Em alguns momentos, isso fica evidenciado pela inserção de discursos diretos no texto; mesmo assim, não se explicitam as emoções. Todas elas têm de ser inferidas pelos interlocutores-ouvintes durante o desenrolar da narrativa.

Esse vínculo de estados emocionais constantemente inferido pelos interlocutores-ouvintes faz parte da necessidade de composiciona-lidade hermenêutica que se exige para que a narrativa seja tomada como um fenômeno completo. Dessa maneira, se os interlocutores-ouvintes não se dispõem a inferir os vínculos de estados emocionais, ou não se dispõem a aceitar que há coerência entre as particularidades, ou entre estas e o mundo referencial, a simples diacronicidade não será suficiente para sustentar a narrativa e isso acarretará tanto a perda da credibilidade como a do direito ao turno longo que foi concedido ao enunciador-narrador. De maneira geral, é necessário que os interlocutores-ouvintes aceitem que os menores iam a bailes em casas de tolerância, que as patrulhas existiam, que os guris sabiam orientar-se à noite sob a luz do luar, que a polícia queria pegar os meninos menores, que os menores tinham medo que os policiais os alcançassem, que um menino corresse tão rápido que 
o lobisomem não fosse capaz de perceber a sua passagem e outros fatos como esses. Essa aceitação caracteriza exatamente a composicionalidade hermenêutica, na medida em que é ela que dá a unidade à narrativa. Se os interlocutores-ouvintes não reconhecem que há coerência entre os fatos narrados, sejam eles intenções, emoções, particularidades ou referências, não haverá sustentação para que o enunciador-narrador continue a manter a atenção sobre o seu enunciado e, consequentemente, para manter a própria narração.

Muitas das coerências entre emoções, particularidades, referências, intenções decorrem da própria formação da sociedade. Como já vimos antes, quando tratamos do acréscimo narrativo, em que o enunciador-narrador chama a atenção para o seu próprio desempenho nos papéis sociais que assume, também se pode verificar que o desempenho dos papéis sociais das demais personagens conduz o desenvolvimento da narrativa. Para tanto, é necessário ter o conhecimento óbvio de que policiais prendem indivíduos que não seguem as leis, que os meninos gostam de bailes, que existem casas de tolerância, que não se deve andar sozinho em noites de lua em lugares ermos. Esses fatos fazem parte da normatividade própria da sociedade. De maneira geral, a fuga a essas normas é que desencadeia os eventos complicadores próprios de uma sentença narrativa.

Na própria sentença de orientação "Porque nós ia pro baile antigamente polícia ia atrás de nós no baile", o enunciador-narrador já apresenta a regra geral cuja expectativa será violada, como elemento complicador. Daí em diante, uma série de fatos se sucede cronologicamente, estabelecendo violações encadeadas, como podem ser vistos alguns exemplos na tabela que vai a seguir. 
Waldemar Ferrelra Netto

\begin{tabular}{|c|c|c|}
\hline \multicolumn{2}{|c|}{ Canonicidade } & Violação \\
\hline fato & expectativa & ocorrência \\
\hline $\begin{array}{l}\text { era uma casa de uma } \\
\text { muierada lá e não podia } \\
\text { ficar de menor de jeito } \\
\text { nenhum }\end{array}$ & menores não entrariam lá & $\begin{array}{l}\text { Então fica um sondando } \\
\text { [enquanto os outros estão lá } \\
\text { dentro] }\end{array}$ \\
\hline chegô a patrulha & $\begin{array}{l}\text { a polícia prendeu os que não } \\
\text { seguiam a lei }\end{array}$ & $\begin{array}{l}\text { Nós currimo na casa da } \\
\text { dona do baile }\end{array}$ \\
\hline $\begin{array}{l}\text { Nós fiquemo escondido } \\
\text { embaixo da mesa }\end{array}$ & não seriam encontrados & $\begin{array}{l}\text { a patrulha, fazendo a revista } \\
\text { por lá, achou nós lá }\end{array}$ \\
\hline $\begin{array}{l}\text { passei um córgo que até } \\
\text { chama córgo João Guia. }\end{array}$ & $\begin{array}{l}\text { a polícia passaria pelo } \\
\text { mesmolugar }\end{array}$ & $\begin{array}{l}\text { Aí ele não pôde cum nós. } \\
\text { Ele não quis molhar a } \\
\text { botina dele }\end{array}$ \\
\hline $\begin{array}{l}\text { Eu extraviei dos compa- } \\
\text { nheiro }\end{array}$ & $\begin{array}{l}\text { voltaria para reencontrá- } \\
\text { los }\end{array}$ & $\begin{array}{l}\text { "Se eu volta pra lá essa } \\
\text { turma vai me pegar ainda. } \\
\text { Eu vou embora pra casa." }\end{array}$ \\
\hline $\begin{array}{l}\text { Vi aquele tareco preto que } \\
\text { vem vindo. Eu falei "ih::: } \\
\text { ai, ai, ai! Já pra trás." }\end{array}$ & $\begin{array}{l}\text { a fuga seria na direção } \\
\text { contrária }\end{array}$ & $\begin{array}{l}\text { Já era uma metade grande } \\
\text { pra mim voltar, né? Lá vai } \\
\text { eu pra frente. }\end{array}$ \\
\hline Ele chegou uma distância... & eu deveria ter sido visto & $\begin{array}{l}\text { Acho que ele nem me viu } \\
\text { direito }\end{array}$ \\
\hline $\begin{array}{l}\text { Daqui eu arranco. Eu passo } \\
\text { perto desse bicho }\end{array}$ & $\begin{array}{l}\text { a velocidade garantiria a } \\
\text { segurança }\end{array}$ & $\begin{array}{l}\text { ele não vai vê que eu vô } \\
\text { correndo daqui pra lá }\end{array}$ \\
\hline
\end{tabular}

Nota-se que o desempenho dos papéis sociais propostos aos personagens, os vínculos de estados emocionais, delineiam o comportamento canônico de cada um deles bem como as suas variações possíveis. Na medida em que a narrativa tem de desenvolver-se por meio de sentenças complicadoras, as ações descritas nessas sentenças são exatamente a descrição do comportamento realizado em oposição ao comportamento idealizado, isto é, a sociedade forma-se por meio da atribuição de papéis sociais com desempenhos previamente estabelecidos, e a sua violação faz parte da reflexão sobre as consequências igualmente previstas. Se a violação dos cânones causa um resultado positivo, isto é, a personagem sai vitoriosa, aquele desempenho poderá ser preconizado e, eventualmente, tornar-se canônico, deixando de ser possível a sua utilização numa sentença complicadora. Dessa maneira, a mudança social tem seu reflexo nas narrativas produzidas. Caso não passem por esse processo de adaptação à nova realidade, perderão completamente a credibilidade e serão transfiguradas em formas folclóricas, caso se mantenham existindo. 


\section{A adequação dos modelos comportamentais exemplares}

Dentre as diferentes possibilidades de adequação dos modelos comportamentais exemplares, podemos referir a transformação das histórias exemplares. Essas histórias foram especialmente referidas por Malinowski em seu trabalho "Mito na psicologia primitiva" (MALINOWSKI, 1988), que foi publicado nos anos vinte, quando propôs sua tripartição em contos, lendas e mitos — categorias, segundo ele, propostas pelos próprios trobriandeses, que as chamavam kukwanebu, libwogwo e liliu, respectivamente. Embora Malinowski estabeleça uma hierarquia de importância entre essas três categorias, é possível tomá-las todas a partir do mesmo ponto de vista. Na medida em que narrativas apresentam suas personagens como representações simbólicas do ambiente social, sua manipulação permite o estabelecimento de modelos comportamentais, a partir dos quais os membros da sociedade podem avaliar seu próprio comportamento e verificar o alinhamento entre eles. A dinâmica da transformação do comportamento das personagens resulta da mudança dos vínculos de estados intencionais, nas palavras de Bruner (1991), como se verá mais adiante. Qualquer que seja a natureza das personagens atuantes numa história exemplar, suas ações estão sempre voltadas para um propósito comum entre os membros da sociedade. $\mathrm{O}$ sucesso ou o insucesso das ações das personagens associam-se a suas consequências emocionais: frustração, raiva, desejo, alegria, dentre várias possibilidades; ainda que as mesmas não estejam claramente manifestas, podem ser previstas e, virtualmente, experimentadas.

Um exemplo de fácil percepção desse tipo de mudança pode ser encontrado no conto que atualmente é conhecido como "A bela adormecida" ou "A bela adormecida do bosque". Giambattista Basile, no início do século XVII, transcrevera conto semelhante: "Sole, Luna e Talia". No conto de Basile, a bela moça Tália, que fora deixada pelo pai, inconsciente e isolada no bosque, é alvo de ato sexual por um rei da vizinhança. Como resultado desse ato, Tália tem dois filhos (Lua e 
Sol). O rei apaixona-se pela moça e passa a frequentar a casa onde morava Tália. A rainha, enciumada pela atitude do marido, chama Tália e seus filhos para viver no castelo a fim de matá-los. Quando a rainha ia alcançar seus intentos, com Tália despida em praça pública, pronta para o sacrifício, o rei chega, salva Tália e seus filhos e imprime à rainha o castigo que considera conveniente. (ver Anexo)

Outro exemplo é o conto recolhido por Charles Perrault. Quando nasceu a princesa, uma das fadas que não fora agraciada com um presente pelo rei, por desfeita, lançou um encanto que acabou tendo por consequência fazer a princesa dormir por muitos anos. Ao realizar-se o encanto, todos os demais dormem junto da princesa. Passado muito tempo, um príncipe entra no castelo, escondido sob a mata fechada, encontra a princesa que, também por encanto, desperta ao sentir o toque da mão do príncipe. Ambos se apaixonam e têm dois filhos (Dia e Aurora). O príncipe leva-os todos para viver em seu castelo. Num determinado período, em que o príncipe tem de ausentar-se, a rainhamãe, que era uma ogra, decide comer os três novos membros de sua família. Não sendo bem-sucedida no seu intento, decide matar a todos, inclusive seu próprio mordomo, que, apesar de ter ajudado a trazer todos para o castelo, tentara salvar os três. Mas o príncipe chega a tempo, salva sua família, é condescendente com o mordomo, e castiga a mãe da maneira que julga conveniente. (ver Anexo)

Embora haja semelhanças importantes nas duas narrativas, o que nos garante que participam de uma mesma tradição (VANSINA, 1966), as diferenças no comportamento das personagens apontam para um processo de adequação de valores. No conto de Basile, há o abandono da filha inconsciente pela família, há a violência sexual praticada pelo rei, há a traição ao casamento monogâmico pela formação de uma família paralela à oficial e, ainda, há a tentativa de assassinato por ciúme e a humilhação em praça feita pela rainha à amante do marido. No conto de Perrault, o abandono da filha inconsciente foi substituído pela inconsciência coletiva de todos, a violência sexual foi substituída 
pela proximidade do príncipe, a traição ao casamento monogâmico foi substituída pela troca das personagens (o rei era casado, o príncipe é solteiro), a tentativa de assassinato, o ciúme e a humilhação em praça foram substituídos pela troca da natureza da personagem (a rainha ciumenta torna-se uma ogra de natureza perversa).

Algumas identidades podem ser percebidas: caberia ao rei e ao príncipe querer e executar, a despeito das consequências de seus atos. As ações do rei ou do príncipe não permitiriam qualquer julgamento. As ações da rainha, entretanto, apesar de igualmente não permitirem qualquer julgamento, não poderiam conflitar com as do rei ou com as do príncipe, qualquer que fosse a motivação que tivessem. De outro, há mudança nas intenções das personagens que são particularmente notáveis: o rei simplesmente estupra, o príncipe apenas toca as mãos da princesa adormecida; o rei trai, o príncipe quer casar; a rainha quer matar por ciúme, a rainha-mãe quer matar por sua natureza sobrenatural... Em nenhum dos contos o estupro e a traição foram condenados, mas tão-somente foram substituídos. Já as ações da rainha contra a vontade do rei, por ciúme ou pela sua natureza má, foram sempre condenadas. Ao que parece, a mudança que as narrativas refletem concentram-se no estupro e na traição conjugal. Em que pese a imunidade real, o estupro e a traição deixam de ser preconizados pela sociedade como comportamentos possíveis.

O cotejo da narrativa indiana "Os ressuscitadores de leões" (SILVA, [19— ] ] com a fábula de Esopo recontada por Monteiro Lobato, "Assembleia dos ratos" (LOBATO, 1957), pode ser outro exemplo. Na narrativa indiana, quatro irmãos brâmanes, reunidos para discutir seu futuro, decidiram sair de viagem em busca de riquezas, mesmo sabendo que um dos irmãos, o mais calado, não era estudado. Durante a viagem, encontraram a ossada de um leão e se dispuseram a ressuscitá-

* Agradeço à Profa. Dra. Maria Valíria Aderson Mello Vargas pela indicação das narrativas. 
lo para provar sua magia. Um ordenaria os ossos, outro juntaria a carne e a pele e o último lhe daria a vida. Quando era a vez do terceiro dar vida ao leão, o irmão que não estudara disse-lhes que o leão poderia matá-los quando ganhasse vida. Temendo isso, pediu que esperassem um pouco para que ele subisse numa árvore. Fez isso e se salvou porque, quando o leão ressuscitou, matou aos três que confiaram em seus conhecimentos e não tomaram as cautelas necessárias. O texto de Lobato, por sua vez, trata de ratos que viviam atormentados por um gato. Quando ocorreu de ele ausentar-se por um período, os ratos se puseram a deliberar sobre o que fazer para resolver esse problema. $\mathrm{O}$ ancião propôs que fosse colocado um guizo no gato, assim todos ouviriam sua aproximação e teriam tempo de fugir. O problema era colocar o guizo no gato. Quando houve a deliberação de quem o colocaria, todos, um a um, abandonaram a reunião dando uma desculpa.

Em que pese a diferença entre as personagens - brâmanes e ratos, gatos e leões — ou das particularidades — guizos e ressuscitamento - verificam-se os mesmos vínculos de estados intencionais de Bruner (1991). Brâmanes e ratos apresentam uma proposta de atuação que os colocaria ao alcance de um inimigo poderoso. Nas duas narrativas há a fuga de alguns quanto à realização desse propósito arriscado. $\mathrm{O}$ vínculo de estados intencionais garante a identidade das narrativas. A referencialidade, por sua vez, necessita de adaptações, pois a possibilidade de ressuscitar uma carcaça de leão não seria facilmente aceita num contexto em que essa habilidade estaria restrita às divindades. Num caso como esse, não será fácil verificar diacronicamente o sentido da mudança, mas sim as razões sociais de suas mudanças. Os ratos, apesar de personificados, não realizariam uma façanha de divindades, os brâmanes, sim. A atribuição dessa habilidade divina aos ratos da narrativa, ou a sua supressão, parece decorrer de um processo de mudança social em que essa habilidade deixou de fazer parte dos papéis sociais que os indivíduos podem adquirir nessa sociedade. 
No fragmento extraído de Tangerino (1996), que reporta uma narrativa guarani, os papéis exemplares ficam relativamente enfatizados.

Koxijá é índio encantado. Branco fala que é capitão do mato. Como você chama aquele que vive no mato, aquele capitão do mato? Se você matar o porco, não pode matar à toa, senão ele acha ruim. Não pode matar porque eu vou contar.

Quando eu morava lá no estado do Rio de Janeiro tinha um homem que era caçador. Ele [Koxijá] foi lá e disse que brigou para não matar mais porco do mato, koxi, pois o dono dele achou ruim, e veio como velhinho com bengala e o homem quase que correu e ele [Koxijá] falou assim:

— Pára, pára, pára!

homem parou, ficou tremendo, e ele falou assim:

- $\bigcirc$ que você quer?

E o homem falou:

- Estou caçando aqui.

- Cuidado! Dono do encantado vai achar ruim!

Daqui a pouco veio a cobra, com asa e tudo e falou assim:

- Se você não obedecer, você vai morrer ali.

Diz que tinha um pauzinho assim e falou:

— Levanta meu corpo.

Aí levantou, era osso puro. Disse ele:

- Quantos você matou?

— Já matei oito porcos.

E ele:

— Então você vai ver, pode vir mais.

Dizem que pegou o pau assim, aí rancou o vento. Quando parou o vento, chegou um velhinho lá e disse:

- Quantos porcos você já matou?

- Sete porcos.

— Você não pode, junta os ossos para você me acreditar, junta os ossos aí, a caveira, o osso.

Depois ele pegou um pau e mandou:

- Levanta o meu porco aí rom...rom..

Aí ele levantou, era o osso puro. É assim o dono do porco, é Koxijá, é índio encantado. (TANGERINO, 1996, p. 79-80)

Embora sejamos capazes de definir o conjunto como um texto narrativo, há incoerências pontuais decorrentes da impossibilidade de se verificar conhecimento compartilhado. Desse ponto de vista, nossa dificuldade decorre do fato de não percebermos exatamente as questões relativas à normatividade e à canonicidade e violação. No que diz 
respeito à canonicidade, entende-se que houve uma violação quando uma das personagens insiste na caça aos porcos do mato. Por meio da inserção da segunda personagem — o Koxijá, 'dono dos porcos' — a regra de proibição é evidenciada e, com ela, a sua violação. O koxi é um dos animais sagrados para os Guaranis, cujo dono, Koxijá, é o Karaí Ru Ete, responsável pelo fogo e um dos deuses primordiais da criação (CADOGAN, 1992a; 1992b). A normatividade só se faz perceber pelo conhecimento das narrativas de origem dos Guaranis. Trata-se, portanto, de uma atualização das narrativas de origem, com um esboço de referencialidade nas primeiras sentenças orientadoras. Ao afirmar que "Se você matar o porco, não pode matar à toa, senão ele acha ruim", o narrador estabelece o princípio geral que deve reger as caçadas. A personagem que teria caçado oito kochi, porco do mato, receberá a repreensão do Koxijá. Em seguida, a partir da descrição da descoberta da matança indiscriminada de koxi, o narrador apresenta a sentença complicadora com a primeira informação sobre a violação, "Ele [Koxijá] foi lá e disse que brigou para não matar mais porco do mato". Ele desenvolve a diacronicidade da narrativa a partir dessa violação. $\mathrm{O}$ evento culminante, ao contrário da expectativa que temos, é justamente a descrição das atividades do próprio Koxijá, capaz de reconstituir seus koxi a partir dos ossos, demonstrando, assim, sua natureza sagrada.

Os vínculos de estados emocionais, os quais conduzem nossa interpretação dos fatos mediante o reconhecimento dos desejos, frustrações, rancores, melancolias, satisfações, e todos os demais sentimentos tipicamente humanos a que estamos acostumados, levam-nos a atribuir medo ao "caçador" ao se encontrar com o Koxijá, estabelecendo uma relação direta entre o exagero na matança e a ira sobrenatural que a matança desencadeia. Para não despertar a ira, é fundamental coibir os desejos e os excessos na caçada.

A compreensão da narrativa está especialmente associada ao nosso conhecimento de fatos culturais específicos a partir dos quais ela se desenvolve. Apesar da característica da composicionalidade 
hermenêutica, todas as demais características são necessárias para a sua perfeita interpretação: desde as características formais, ou de nível baixo, como eu as defini, até as que conside-ram a relação entre os fatos narrados e a cultura, ou as de nível alto. O narrador guarani, em que pese ter feito a narrativa em língua portuguesa, leva em consideração os fatos culturais com os quais está familiarizado, trazendo à tona o contexto de enunciação na sentença inicial de orientação, quando dá as informações necessárias para a compreensão da narrativa a ser feita. É a característica de sensibilidade ao contexto e negociação. No entanto, nem todos os dados apresentados podem ser prontamente interpretados, uma vez que nos falta esse conhecimento partilhado. As particularidades da "cobra com asa" e do "vento" tornam-se elementos cuja compreensão exige um maior adentramento cultural e uma maior familiaridade com as demais narrativas que tratam desses fatos.

Por outro lado, nem sempre as narrativas exemplares, que apontam os comportamentos esperados, reportam eventos sobrenaturais. Na maior parte das vezes são naturais mesmo.

Aqui no correntoso também eu escapei de ser pego por três: o casal e o filhote. Eu ia desceno sozinho de barco. Ih! Aí, o barco subiu em cima dum toco. Eu desci dentro d'água, ergui o barco e, quando eu joguei, ela rosnou pertinho de mim. Tava a base duns dez metro longe de mim. Daí, se eu continuasse, ela ia pulá ni mim $e$ ia me pegá por causa que o rio tava muito estreitinho e tava raso. A água tava aqui assim. É uma onça, é... pintada. Era o casal. Casal e um filhote. Então, aí, eu quase eu pensei "eu vô voltá... de volta porque ela vai me pega." Quando eu olhei assim, ela tinha saído. Aí, eu escondi atrás da borda do barco. Fiquei escondido, abaixado. Ih! $\bigcirc$ filhote veio direto no barco e cheirou a borda do barco e eu, escondido do outro lado. Aí, veio a mãe e pai também ali. Cheirou o barco e eu escondido atrás. Eu falei "hoje daqui eu num... eu tô morto, né?" Então, são os perigo que eu já passei no Pantanal. (PINTO, 2006, p. 235)
A narrativa pessoal (quadro ao lado) que descreve o encontro do enunciador-narrador com a onça reporta um testemunho relativo ao comportamento desse animal numa circunstância bastante inédita. Eram três animais, formando um casal com um filhote. Após o contato direto, o enunciador-narrador descreve o comportamento dos animais que se aproximaram, primeiro o filhote e em seguida a fêmea e o macho. Cheiraram e desistiram da busca. Essa descrição sugere que a atuação do enunciadornarrador no momento descrito foi a 
ideal. De certa forma, ela rompeu o cânone de que, ao se aproximar, a onça necessariamente ataca. No caso, a inocorrência do ataque decorreu da atitude acertada que tomou o enunciador narrador, escondido, quieto, atrás do barco.

\section{A substituição dos meios de comunicação}

A proposição de McLuhan (1979) de que os meios podem acumular-se formando meios cada vez mais complexos permite-nos diferenciá-los como meios de nível alto e de nível baixo. Referindo-se estes especialmente às características materiais da transmissão, tais como as ondas sonoras, as ondas eletromagnéticas, o papel, o lápis, a tipografia, a documentação magnética, dentre outras possibilidades; e aqueles, às características compostas por diversas camadas de significação, tais como os gêneros textuais, as personagens das narrativas, os recursos estilísticos, dentre outras possibilidades. Trata-se, obviamente, de uma divisão ad hoc, com fins puramente explicativos. Meios de nível alto e de nível baixo permitem uma gama muito grande de níveis intermediários, mas, em todos esses níveis, entende-se que o procedimento para a mudança tem o mesmo princípio da formação em camadas, cujas novas características decorrem do acréscimo ou da supressão de característica do nível sobre o qual se construiu o novo meio.

Esse tipo de mudança nas narrativas poderia mostrar-se pelo cotejo da narrativa grega "Bóreas e o Sol", compilada por Esopo, e a narrativa taulipang "Onça e Chuva", compilada por Koch-Grünberg. A narrativa de Esopo, "Bóreas e o Sol", tem como personagens dois fenômenos meteorológicos personificados, que disputam entre si quanto a suas forças, tentando despir um homem. Bóreas, o vento, torna-se mais e mais intenso e tudo o que consegue é fazer o homem agarrar-se mais a suas roupas. O Sol, ao tornar-se mais intenso, faz o homem despir-se. A narrativa de Koch-Grünberg, "Onça e Chuva", tem como personagens um animal e um fenômeno meteorológico personificado, 
também disputando entre si quanto a suas forças, tentando fazer umas pessoas que haviam saído da maloca tornarem para dentro. A onça passeia pelas redondezas roncando forte para assustar as pessoas, e tudo o que consegue é fazer os homens decidirem flechá-la quando pudessem, sem demonstrar medo; a chuva, entretanto, com facilidade faz as pessoas voltarem à maloca.

À semelhança do que vimos na comparação, há adequações diversas, mas não há mudanças nos vínculos de estados intencionais, o que garante a identificação das narrativas. $\mathrm{O}$ que nos chama a atenção na narrativa taulipang, entretanto, é a atribuição de estados intencionais à chuva e à onça simultaneamente. Embora a personificação desses elementos seja comum em várias narrativas indígenas, não é comum que sejam concomitantes. No esquema geral de Bruner (1991), há o rompimento com a referencialidade. Segundo ele, a "verdade" narrativa é julgada por sua verossimilhança e não por sua verificabilidade. Isso parece apontar para o fato de que há algum sentido em dizer que a narrativa, mais do que referir a "realidade", pode criá-la da mesma maneira que a "ficção" cria um "mundo" para si própria. No caso particular dos taulipang, há que se pensar em qual contexto mítico, divino ou religioso seria possível localizar a narrativa tal como foi proposta. A introdução de um novo traço, a concomitância de estados intencionais a particularidades tão diferentes como a chuva e a onça possibilita o estabelecimento de novas interpretações dos próprios fenômenos meteorológicos.

A mudança tecnológica que promove o desenvolvimento de novos papéis sociais pode ser referida a partir do trabalho de Raul Reis, que analisou o impacto do surgimento da televisão na cidade de São João de Pirabas, no Pará, no ano 1996 (REIS, 1998). O autor descreve a cidade, enfatizando as relações sociais mantidas pelo contato interpessoal entre os habitantes. Segundo ele, no início da noite, os moradores jovens da cidade participavam de uma atividade externa, a que chamam de movimento, na qual todos podem se encontrar. A presença 
da televisão, entretanto, promoveu uma mudança na rotina mantendo jovens e adultos dentro de casa, vendo novelas, diminuindo significativamente a atividade externa do movimento. Mais do que uma mudança de hábito, o acesso constante à nova informação promoveu na cidade uma reavaliação dos papéis sociais disponíveis para os seus cidadãos. $\mathrm{O}$ autor refere uma moça que optara por um emprego de empregada doméstica em Belém, mostrando-se bastante interessada pela possibilidade de mudança para uma grande cidade; refere um rapaz que optara por uma carreira fora da cidade, pois, devido a sua educação escolar, não iria querer um trabalho como pescador. Outra moça salientara que tinha de vestir-se de maneira semelhante às personagens das novelas porque não tinha que se "vestir como bichodo-mato" (op. cit. p. 304).

Conforme o trabalho de Reis (1998), a mudança nos padrões de avaliação que verificou na cidade de São João de Pirabas teve sua origem na presença dos aparelhos de televisão cuja programação deu-lhes acesso a novos paradigmas comportamentais. A mudança, portanto, decorreu da possibilidade de acesso a uma rede de significações que suprimia a idealização dos comportamentos locais e acrescentava a idealização de outros comportamentos, praticados em centros urbanos muito mais densamente povoados. $\mathrm{O}$ fato de a mudança de paradigmas não ter sido resultado de uma mudança comportamental interna da sociedade, mas ser o resultado da inserção tecnológica, é um fato significativo de que o meio pôde atuar como previra McLuhan (1979), transformando papéis sociais que, por sua vez, atuam como formas exemplares de comportamento.

Grosso modo, nota-se que os meios de informação referido no trabalho de Reis (1998) acumulam pelo menos dois outros: o gênero televisivo das novelas e a tele-transmissão por ondas eletromagnéticas de sons e de imagens simultaneamente. Ainda que sejam fenômenos que possam ser tratados com independência, não é possível desvinculálos entre si do processo geral, isto é, uma interferência na transmissão 
Tradição Oral e produção de narrativas

das ondas eletromagnéticas interfere diretamente no resultado no processo. $\mathrm{O}$ inverso, entretanto, não é verdadeiro: o gênero televisivo da novela não interfere na transmissão. 


\section{ANEXOS}

\section{Sol, Lua e Tália \\ Gianfrancesco Basile}

trad. do italiano por Waldemar Ferreira Netto

Era uma vez um grande senhor, que, quando nasceu sua linda filha, deu-lhe o nome de Tália e chamou todos os sábios e os astrólogos do reino para que predissessem seu futuro. Eles consultaram as estrelas e se aconselharam durante algum tempo, e depois disseram:

- Tália será bela e cheia de graça, mas arriscará a morrer por uma farpa de linho.

Esperando evitar a desgraça, o senhor decretou que ninguém em sua casa tivesse ou trouxesse mais linho, nem mesmo cânhamo, nem qualquer coisa semelhante.

Mas, quando Tália já era uma mocinha, um dia, em que estava na janela, viu passar uma mulher velha que fiava; e ela, que nunca tinha visto uma roca nem um fuso, interessou-se muitíssimo pela maneira como girava. Teve um desejo tão grande de ver o instrumento de perto que convidou a senhora a deixar a lei de lado e, pegando a roca na mão, tentou estirar o fio, mas uma farpa de linho entrou sob sua 
unha, e, naquele mesmo instante, ela caiu por terra, morta; quando a velha viu o que tinha acontecido, tomou as escadas e foi de volta para a rua.

O pobre pai, diante dessa desgraça, chorou um pote de lágrimas e se sentiu inundado de tristeza. Então deixou a belíssima Tália em seu palácio de campo sentada num trono de veludo, sobre uma almofada de broquel, depois fechou todas as portas e, então, abandonou para sempre aquele palácio, esperando esquecer a desgraça e superar a terrível dor que isso lhe causara.

Depois de muito tempo, passou um rei que estava caçando, e o seu falcão fugiu, voou para uma janela aberta do palácio e não voltou mais ao seu chamado. Então, o rei mandou baterem à porta do palácio, acreditando que lá habitasse alguém, mas ninguém respondia. Assim, mandou colocar uma escada de vindimador e quis ir lá para ver o que havia naquele palácio.

Andou por todos os lados e ficou impressionado porque não tinha alma viva; finalmente abriu a porta do quarto onde estava Tália sob encantamento e, pensando que ela estivesse adormecida, chamoua, mas ela não respondeu. Então, tentou reanimar a belíssima jovem pensando que tivesse passado mal, mas foi inútil. Enfim, inflamado por sua beleza, tomou-a pelos braços e deitou-a em seu leito, beijou-a e lhe deu todo seu amor. Depois, deixando-a lá estendida, voltou ao seu palácio, e por algum tempo não pensou mais no que havia acontecido.

Depois de nove meses, Tália pariu duas crianças, um menino e uma menina, que resplandeciam de beleza como ouro e diamante, e que foram cuidadas por duas fadas que apareceram no palácio e as colocaram junto ao seio de sua mãe.

Um dia, os gêmeos, querendo mamar, sem encontrar o bico do seio, puseram na boca o dedo de Tália, e tanto chuparam que fizeram sair a farpa de linho. 
Então, pareceu à Tália que despertava de seu longuíssimo sono, depois viu junto de si aquelas duas belíssimas crianças e, muito contente, deu-lhes de seu leite, e tinha-lhes carinho como a sua própria vida.

Tália não entendia o que havia acontecido, e se encontrava muito só naquele palácio com seus gêmeos, enquanto lhes serviam de comida, sem que pudesse ver quem lhes dava; foi quando o rei se lembrou daquela bela adormecida.

Voltou à caça e, chegando à frente do palácio, entrou para vê-la, e assim a encontrou acordada com aquelas duas crianças muito belas e alegres, e ficou feliz como nunca havia ficado antes.

Contou à Tália quem era e como tudo aconteceu. Assim se conheceram e se quiseram muito bem, e passaram juntos alguns dias. Depois a deixou só, prometendo-lhe que voltaria logo para tê-la consigo, e foi para o seu reino, onde se lembrava durante todo o tempo de Tália e de seus filhos, tanto que, enquanto comia tinha em seus lábios Tália, Sol e Lua, que era assim que tinha chamado as crianças, e não dormia nem acordava sem pronunciar o nome deles.

A rainha, vendo que ele ficava tanto tempo longe por causa da caça, suspeitava de alguma coisa, e, percebendo que ele não fazia outra coisa senão chamar por Tália, Sol e Lua, ficou furiosa de ciúmes. Chamou seu secretário e lhe disse:

— Sinto muito, meu querido, mas não te convém refutar o que te peço, por que se me diz por quem o rei está apaixonado te faço enriquecer, se me esconder te farei torturar.

O secretário, por um lado, estava apavorado, mas por outro estava ávido de riquezas e, esquecendo-se de ter falado de honra, de justiça ou de fidelidade ao rei, contou tudo o que ela queria saber.

Então a rainha lhe ordenou ir aonde estava Tália para dizer-lhe que o rei queria as crianças no palácio.

Tália não ficou feliz mas mandou Sol e Lua com o secretário, que os colocou nas mãos da rainha, e ela, que era mais venenosa do que 
uma víbora, mandou o cozinheiro descarná-los e cozinhá-los em vários molhos para fazer um jantar ao rei.

Mas o cozinheiro, por sorte, era de coração mole e, vendo aquelas duas belas criancinhas, teve pena delas, assim, depois de as enviar à sua mulher para que não houvesse problema, preparou dois cabritos ao louro, segundo certa receita.

Quando o rei chegou, a rainha muito satisfeita fez pôr a mesa e o rei, enquanto comia com gosto, exclamava:

- Nossa! Como isso é bom! Que saboroso este outro!

Ela the retrucava:

- Come, que está comendo a sua carne.

O rei teve um certo aborrecimento e lhe disse: - Eu sei que como minha carne, porque eu sou o rei e todos os bens são meus, porque de seu não há nada - e em seguida levantou e foi dar uma volta na campina para fazer passar a raiva.

Mas para a rainha ainda não bastava o que ela havia feito, e assim ordenou ao secretário para chamar Tália com a desculpa de que o rei a esperava.

Tália, contente, se preparou e partiu imediatamente, cheia de desejo de ver o rei, e não sabia que caminhava para as garras de sua inimiga.

Assim que chegou à frente da rainha, esta, com expressão cruel e com voz pérfida e irônica, lhe disse:

- Ahá. Seja bem-vinda, senhorita mulherzinha da vida! É você a cadelinha que tem enganado o rei, você é a trejeitosa que quer tê-lo todo para si! É você, menininha porcalhona, com quem ele passa tanto tempo! Você chegou ao seu tribunal, porque agora eu vou dar a punição que você merece!

Tália começou a pedir desculpas, dizendo que não era sua culpa, que o rei tinha ido à sua propriedade enquanto ela estava encantada, mas a rainha não quis ouvi-la. 
Acendeu-se o grande fogo que a rainha tinha mandado preparar no pátio do palácio e deu ordem para que a colocassem para queimar.

Vendo que as coisas iam mal, Tália se ajoelhou diante da rainha e lhe disse:

- Imploro, me deixe ao menos tempo de trocar este belo vestido que estou usando.

Não por piedade, mas por lhe agradar a ideia de tomar aquele vestido adornado com ouro e pérolas, a rainha lhe disse:

- Está bem, dispa-se.

Então, Tália começou a despir-se lentamente, e a cada peça de roupa que despia, soltava um grito. Assim, quando já retirara o manto, a jaqueta e a saia, no momento de retirar a roupa de baixo, deu o último grito, a tirou e a estava colocando no fogo onde a rainha queria transformá-la em um monte de cinzas, quando chegou o rei e, encontrando-se diante daquela cena, ordenou que ninguém se movesse. Quis saber o que estava acontecendo, e quando perguntou pelas suas crianças, a rainha cruel lhe disse: - Quanto a isso não há mais remédio, porque fiz que você as comesse e que as saboreasse com gosto.

O rei, enlouquecido, chorava e gritava:

- Pobres filhinhos meus, agora eu sou o seu lobo assassino. Como é possível que eu não tivesse reconhecido a sua carne que eu tanto acariciei?! E você, bruxa pérfida e renegada, como pôde ser mais feroz do que os animais selvagens? Mas eu não te darei tempo para pedir perdão por seus pecados.

E deu ordem para que a rainha fosse jogada no fogo que ela mesma tinha mandado preparar para Tália, mandou queimar com ela também o secretário, que foi seu cúmplice, e mandou que queimassem também o cozinheiro que tinha retalhado e cozinhado seus meninos. Mas o cozinheiro colocou-se aos seus pés e disse:

- Senhor, seria o fogo a recompensa pelo serviço que lhe fiz?! Assim me retribui, enquanto asso preso a um pau? É esta a boa posição 
que me faz ter: na grelha com a rainha? Eu esperava alguma coisa melhor por ter salvado as duas crianças, desobedecendo àquele coração de pedra que queria que você as comesse!

Ao ouvir essas palavras, o rei ficou atônito, e pensou que fosse um sonho, porque não conseguia acreditar naquilo que chegava a seus ouvidos. Em seguida, voltou-se ao cozinheiro e lhe disse:

- Se é verdade que você salvou os meus meninos, tenha certeza de que mandarei deixar de girar o espeto, e lhe darei o poder de girar o meu coração, porque quero satisfazer em tudo os seus desejos, e lhe darei um prêmio tão grande que você vai ser o homem mais feliz do mundo.

Enquanto ele dizia essas palavras, a mulher do cozinheiro, que tinha visto seu marido em perigo, trouxe Sol e Lua, e o rei os abraçou juntamente com Tália, e, chorando de alegria, não conseguiu saciar-se de beijá-los e acariciá-los.

Depois de ter dado uma boa fortuna ao cozinheiro e de tê-lo nomeado principal cavaleiro do palácio, o rei se casou com Tália, que viveu sempre feliz com o marido e com os filhos, depois de ter descoberto que até dormindo se pode ter fortuna. 


\section{A bela adormecida do bosque Charles Perrault}

trad. do francês por Waldemar Ferreira Netto

Era uma vez um rei e uma rainha que estavam tristes por não ter filhos, tão tristes quem nem se poderia descrever. Foram a todas as águas termais do mundo, poços de desejos, peregrinações, pequenas devoções; tentaram de tudo, mas nada teve resultado.

Até que um dia a rainha engravidou e deu à luz uma menina. Fez-se um belo batizado; convidando para madrinhas da pequena princesa todas as fadas que se encontravam no País (encontraram-se sete), de maneira que cada uma delas ofertasse-lhe um dom, como era o costume das fadas naquele tempo, e a princesa tivesse por este meio todas as perfeições imagináveis.

Após as cerimônias do batizado todos os convidados voltaram ao Palácio do Rei, onde havia um grande banquete para as fadas. $\mathrm{Na}$ frente de cada uma delas pôs-se um jogo de talher magnífico, com um estojo de ouro maciço, onde havia uma colher, garfo e uma faca, com diamantes e rubis. Quando cada uma tomava o seu lugar à mesa, viuse entrar uma velha fada, que não tinha sido convidada porque havia 
mais de cinquenta anos que não saía de uma torre e que se pensava estar morta ou enfeitiçada.

O rei mandou lhe dar um jogo de talher, mas não houve meio para dar-lhe um de ouro maciço, como às outras, porque se tinha mandado fazer apenas sete para as sete fadas. A velha entendeu-se desprezada e murmurou algumas ameaças entre os seus dentes.

Uma fada jovem que estava perto ouviu-a. Achando que a velha fada poderia ofertar algum dom deplorável à pequena Princesa, saiu da mesa para esconder-se atrás de uma cortina e, assim, falar por último, e poder reparar, na medida do possível, o mal que a velha teria feito.

As fadas começaram a ofertar os seus dons à princesa. A mais jovem ofertou-lhe o dom de ser a mais bonita do mundo; a seguinte, o dom de ter alma de anjo; a terceira, de ter uma graça admirável em qualquer coisa que fizesse; a quarta, de dançar perfeitamente; a quinta, de cantar como um rouxinol e a sexta, de saber tocar todos os instrumentos à perfeição.

Quando foi a vez da velha fada, ela disse, agitando a cabeça, mais por despeito do que por velhice, que a princesa haveria de machucar a mão em um fuso e que morreria.

Este terrível dom fez todos os convidados tremerem, e não houve pessoa que não chorasse.

Nesse momento, a jovem fada saiu de trás da cortina e disse em voz alta estas palavras:

- Tranquilizem-se, rei e rainha, a sua menina não morrerá: é verdade que não tenho bastante poder para desfazer inteiramente o que minha antecessora fez. A princesa machucará sua mão em um fuso; mas, em vez morrer, cairá num profundo sono que durará cem anos, no fim dos quais o filho de um rei virá despertá-la.

O rei, para tentar evitar a desgraça anunciada pela velha bruxa, mandou publicar imediatamente um édito, em que proibia a todos de fiar com fuso e de ter fusos, sob pena de morte. 
No final de quinze ou dezesseis anos, o rei e a rainha foram a uma de suas casas de veraneio e ocorreu que, um dia, a jovem princesa, correndo pelo castelo, entrando de quarto em quarto, foi até o alto de uma torre, onde uma velhinha estava fiando sozinha. Essa boa mulher não tinha ouvido falar das proibições que o rei fizera de se fiar com o fuso.

- O que está fazendo, boa senhora? - perguntou a princesa.

- Estou fiando, minha bela criança - respondeu-lhe a velha, que não a conhecia.

- Ah! que beleza! - retomou a princesa - como se faz isso? Deixe-me ver se consigo fazê-lo também.

Nem bem pegou o fuso e, por ser muito ativa e espaventada, e tal como o destino que a fada lhe ofertara, machucou a mão e caiu desmaiada.

A boa senhora, muito assustada, gritou por socorro: todos vieram de todos os lados, jogaram água no rosto da princesa, afrouxaram-lhe a roupa, movimentaram suas mãos, friccionaram suas têmporas com a água da rainha da Hungria; mas nada a fizera acordar.

Então o rei, que acorrera ao barulho, recordou-se da previsão da fada e, julgando que aquilo haveria de ocorrer, dado que as fadas tivessem-no dito, ordenou que colocassem a princesa no mais belo aposento do palácio, sobre uma cama com bordados em ouro e prata. Parecia um anjo de tão bonita; porque o desmaio não lhe tinha tirado suas cores vivas: suas faces eram carmesins e os seus lábios, como coral; tinha apenas os olhos fechados, mas respirava lentamente, o que mostrava que, de fato, não tinha morrido.

$\mathrm{O}$ rei ordenou que a deixassem dormir até que chegasse a sua hora de despertar.

A boa fada que lhe tinha salvo a vida, condenando-a a dormir por cem anos, estava no Reino de Mataquim, a doze mil milhas de lá, quando soube que o acidente chegara à princesa; mas foi avisada por 
um pequeno gnomo, que tinha botas de sete léguas (botas com as quais faziam-se sete léguas com um só passo).

A fada partiu imediatamente, e, ao cabo de uma hora, viram-na chegar num carro de fogo, levado por dragões. O rei ofereceu-lhe a mão para descer do carro. Ela aprovou tudo o que ele tinha feito; mas, como era muito previdente, pensou que, quando a princesa despertasse, se assustaria muito por estar completamente só neste velho castelo.

Eis o que fez: tocou com sua vara de condão em tudo o que estava no castelo (fora o rei e a rainha), criadas, damas de companhia, aias, cavaleiros, oficiais, mordomos, cozinheiros, guardas, cavalariços, pajens; tocou também em todos os cavalos que estavam nas cocheiras, nas estrebarias, nos grandes cães mastim e em Pouffe, a pequena cadelinha da princesa, que estava junto dela na cama.

A partir de seu toque, adormeceram todos, para despertar ao mesmo tempo que a sua senhora, e assim estarem prontos para servi-la quando tivesse necessidade; os próprios espetos que estavam ao fogo com perdizes e faisões adormeceram, bem como o fogo. Tudo isso se fez só num momento; as fadas não se demoram em seu trabalho.

Então o rei e a rainha, após abraçarem a sua querida criança sem que a despertassem, saíram do castelo e mandaram publicar proibições de se aproximar. Estas proibições não eram necessárias, pois em quinze minutos já surgiram ao redor do parque tantas árvores, grandes e pequenas, trepadeiras de espinhos entrelaçadas umas com as outras, que nem homem nem animal conseguiriam passar; de modo que se via apenas a parte superior das torres do castelo, mesmo assim à distância. Não se duvidava de que isso fosse ofício das fadas, para que a princesa, enquanto dormisse, não tivesse que temer os curiosos.

No final dos cem anos, o filho do rei que, então, reinava e que era de outra família foi caçar naquelas bandas e perguntou o que eram aquelas torres que via acima de um bosque muito grande e muito cerrado; cada um the respondia conforme tivesse ouvido falar. 
Uns diziam que era um velho castelo onde viviam fantasmas; outros, que era onde todos os bruxos da região faziam sabbat. Mas a opinião comum era a de que havia um ogro, que levava para lá todas as crianças que apanhava, para comê-las à vontade, sem que se pudesse segui-lo, pois tinha o poder de fazer-se passar através do bosque.

O príncipe não sabia mais em que acreditar, até que um velho camponês tomou a palavra e lhe disse:

- Meu príncipe, há mais de cinquenta anos que eu ouvi de meu pai que havia neste castelo uma princesa, a mais bonita do mundo; que deverá lá dormir cem anos e que será acordada pelo filho de um rei, para quem ela se destinava.

O jovem príncipe ao ouvir essa história ficou estimulado; acreditou sem vacilar que poria fim a tão bela aventura; e, empurrado pelo amor e pela glória, resolveu ver imediatamente o que era.

Mal avançou para o bosque e todas as grandes árvores e as trepadeiras de espinhos afastaram-se para deixarem-no passar: andou até o castelo que via no final de uma grande trilha por onde entrou, o que o assustou, pois viu que ninguém que o seguisse conseguiria passar porque as árvores se fechavam assim que ele passava.

Entretanto continuou por seu caminho; um príncipe jovem e amoroso é sempre muito valente. Entrou num grande pátio onde qualquer um que o visse seria capaz de congelar de medo: um silêncio terrível, semelhante à morte, apresentava-se por toda a parte; não havia senão corpos de homens e de animais, que pareciam mortos. Reconheceu, no entanto, pela respiração do nariz e pela face vermelha dos guardas, que estavam apenas adormecidos, e por suas xícaras, em que havia ainda algumas gotas de vinho, mostrando claramente que tinham dormido enquanto bebiam.

Passou por um grande pátio pavimentado com mármore, subiu uma escada, entrou na sala dos guardas que estavam em fila, com a arma sobre o ombro e roncando. Atravessou vários cômodos cheios de 
cavalheiros e senhoras, todos dormindo, uns de pé, outros sentados; entrou num cômodo dourado e viu sobre uma cama, cujas cortinas estavam abertas de todos os lados, o mais belo espetáculo que já tinha visto: uma princesa que parecia ter quinze ou dezesseis anos, com um brilho que resplandecia algo de luminoso e divino.

Aproximou-se tremendo e admirando, e pôs-se de joelhos junto a ela. Então, porque chegara o fim do encanto, a princesa despertou e, olhando-o com olhos mais ternos que a primeira visão permitiria, disse-lhe:

- É você, o meu Príncipe? Fez-se esperar muito.

O príncipe, encantado com estas palavras, e mais ainda com a maneira pela qual eram ditas, não sabia como testemunhar-lhe a sua alegria e o seu reconhecimento; assegurou que a amava mais do que a ele mesmo. Os seus discursos foram mal arranjados, com muita desvantagem: pouca eloquência, muito amor. Estava mais assustado do que ela, e não se deve surpreender com isso: a princesa tinha tido o tempo de pensar o que teria a dizer-lhe, pois parece (a história não diz nada) que boa fada, durante sono tão longo, ter-lhe-ia dado o prazer dos sonhos agradáveis. Enfim, havia quatro horas que se falavam e ainda não tinham dito a metade das coisas que tinham a dizer-se.

Contudo, todo o Palácio despertou com a princesa; cada um pensava em fazer o seu trabalho e, como não estavam todos apaixonados, estavam mortos de fome; a dama de honra, pressionada como os outros, impaciente, disse em voz muito alta à princesa que a carne estava servida.

O príncipe ajudou a princesa a levantar-se; ela estava muito bem vestida; mas guardou-se de dizer-lhe que estava vestida como se fora sua avó, além de uma gola bufante; mesmo assim estava muito bonita.

Passaram para o salão de espelhos, e lá jantaram, servidos pelos serviçais da princesa; os violinos e oboés tocaram velhas peças, mas 
excelentes, embora houvesse quase cem anos que elas não fossem mais ouvidas; e, após jantarem, sem perder tempo, o capelão casou-os na capela do castelo, e a dama de honra fechou-lhes a cortina. Dormiram pouco, pois a princesa não tinha grande necessidade e o príncipe deixoua logo pela manhã para voltar à cidade, onde seu pai devia estar preocupado.

O príncipe disse-lhe que esteve caçando e que se perdeu no bosque, e que tinha pousado na choupana de um carvoeiro, que lhe dera para comer pão preto e queijo. O rei seu pai, que era bom homem, acreditou, mas a sua mãe não se convenceu, vendo que quase todos os dias ia à caça, e que tinha sempre uma razão para se desculpar; quando começou a passar duas ou três noites fora, ela não duvidou mais de que ele tinha algum namoro. Ele viveu com a princesa mais de dois anos inteiros, e teve duas crianças, uma das quais, a primeira, que era uma menina, chamou-se Aurora, e a segunda, um filho, chamou-se Dia, porque era ainda mais bonito do que a sua irmã.

A rainha disse várias vezes a seu filho para explicar-se, pois era necessário satisfazer-se na vida, mas ele nunca ousou confiar-lhe o seu segredo. Tinha medo dela, apesar de amá-la muito, porque era da raça dos ogros, e o rei tinha se casado com ela apenas por causa de sua riqueza; dizia-se mesmo, por toda a corte, que tinha as inclinações dos ogros e que, vendo passar pequenas crianças, tinha todas as preocupações para se conter de se lançar sobre elas. Assim, o príncipe nunca quis the contar nada.

Mas, depois de dois anos, quando o rei morreu, e ele tomou seu lugar, declarou publicamente o seu casamento, e foi com grande cerimônia levar a sua mulher a seu castelo.

Fez-lhe uma entrada magnífica na capital, onde entrou no meio de suas duas crianças. Algum tempo depois, o rei foi fazer guerra ao imperador Cantalabutte, seu vizinho. Deixou a regência do reino à rainha-mãe, recomendando-lhe com vivacidade sua mulher e as suas crianças: devia estar em guerra durante todo o verão. Logo que partiu, 
a rainha-mãe enviou sua nora e suas crianças a uma casa de campanha no bosque, para poder saciar mais facilmente o seu horrível desejo.

Algum tempo depois, diz uma tarde ao seu mordomo:

- Amanhã quero comer a pequena Aurora em meu jantar.

- Ah! Senhora! — disse o mordomo.

- Quero-a, disse a rainha (e ela disse com um tom de ogro que tem desejo de comer carne fresca), e quero comê-la com molho Robert.

Esse pobre homem, entretanto, vendo que não poderia discutir com uma ogra, pegou seu facão e foi ao quarto da pequena Aurora, que tinha, então, quatro anos, e que veio saltando e rindo pular em seu pescoço, pedindo-lhe bombons.

Ele se pôs a chorar e o facão lhe caiu das mãos. Foi ao curral cortar a garganta de um pequeno cordeiro e fez com ele um molho tão bom que sua senhora assegurou-se de que nunca tinha comido nada assim tão bom. Ao mesmo tempo levou a pequena Aurora à sua mulher para escondê-la no alojamento que tinha no fundo do galinheiro.

Oito dias depois, a maldosa rainha disse ao seu mordomo:

- Quero comer o pequeno Dia no meu jantar.

Não replicou, pois estava resolvido a enganá-la como da outra vez. Foi procurar o pequeno Dia e encontrou-o com um pequeno florete à mão, com que lutava com um macaco gordo: tinha, no entanto, apenas três anos. Levou-o à sua mulher, que o escondeu com a pequena Aurora, e deu, em lugar do pequeno Dia, um pequeno cabrito extremamente tenro, que a ogra achou que estava muito bom.

Aquilo tinha ido muito bem até aí, mas, uma noite, a maldosa rainha-mãe disse ao mordomo:

- Quero comer a rainha com o mesmo molho de suas crianças.

Foi quando o pobre mordomo desesperou-se de não poder mais enganá-la. A jovem rainha tinha mais de vinte anos, sem contar os cem anos em que tinha dormido: a sua pele estaria um pouco dura, 
ainda que bonita e clara; como ele faria para encontrar no curral um animal como ela?

Tomou a resolução, para salvar a sua própria vida, de cortar a garganta da jovem rainha. Foi ao quarto dela, com a intenção de resolver aquilo de uma vez; excitava-se à fúria e entrou com o punhal na mão no quarto da jovem rainha. Não quis, no entanto, surpreender-lhe e disselhe com muito respeito a ordem que tinha recebido da rainha-mãe.

- Cumpra o seu dever - disse, esticando-lhe o pescoço-; execute a ordem que recebeu; irei rever as minhas crianças, as minhas pobres crianças de quem gostei tanto - porque acreditava que estivessem mortas desde que foram levadas sem nada lhe dizerem.

- Não, não, Senhora - respondeu-lhe o pobre mordomo muito pesaroso - não morrerá não e poderá rever suas crianças, mas será onde as escondi. Enganarei novamente a rainha, fazendo-lhe comer uma jovem cerva no vosso lugar.

Levou-a imediatamente a seu quarto, onde a deixou abraçar as suas crianças e chorar com elas, foi preparar uma cerva, que a rainha comeu em seu jantar, com o mesmo apetite com que comeria se fosse a jovem rainha. Estava bem contente de sua crueldade e preparava-se para dizer ao rei, em seu regresso, que os lobos raivosos tinham comido a rainha, sua mulher, e as suas duas crianças.

Uma noite em que ela rondava, como geralmente fazia, pelas partes do castelo, para farejar carne fresca, ela ouviu na sala de baixo o pequeno Dia que chorava, porque a rainha sua mãe queria chicoteá-lo, por ter sido maldoso, e queria, também, que a pequena Aurora pedisse perdão para seu irmão.

A ogra reconheceu a voz da rainha e das suas crianças e, furiosa por ter sido enganada, ordenou com a voz tonitruante que fazia todos tremerem que, no dia seguinte pela manhã, trouxessem no meio da corte um grande tanque, cheio de sapos, viboras, cobras e serpentes, para jogar lá a rainha, as suas crianças, o mordomo, a sua mulher e sua criada: tinha dado ordem para conduzi-los com as mãos amarradas nas costas. 
Estavam lá, e os carrascos preparavam-se para lançá-los no tanque, quando o Rei, que não se esperava assim tão cedo, entrou na corte a cavalo; tinha vindo no seu posto e perguntou muito surpreso o que era aquele horrível espetáculo; ninguém ousava responder, quando a ogra, raivosa de ver o que via, atirou-se de cabeça no tanque e foi devorada num instante pelos animais que tinha mandado colocar lá.

O rei não pôde dominar sua tristeza, porque era a sua mãe; mas consolou-se rapidamente com a sua bela esposa e com suas crianças. 


\section{Referências}

ARAÚJO, Alceu Maynard. Cultura popular brasileira. São Paulo: Melhoramentos; Brasília: INL, 1973.

BARTH, Fredrik. Ethnic groups and boundaries. The social organization of culture difference. Illinois: Waveland Press, 1998.

BENVENISTE, Émile. O aparelho formal da enunciação. Tradução Eduardo Guimarães et al. do original de 1970. In — Problemas de linguística geral. Campinas: Pontes, 1989. p. 81-90.

BERGSON, Henri. Memória e Vida. Textos escolhidos por Gilles Deleuze. Tradução Claudia Berliner. São Paulo: Martins Fontes, 2006.

BRUNER, Jerome. The Narrative Construction of Reality. Critical Inquiry, [S.1.], 8.1, p. 1-21, 1991.

CADOGAN, León. Ayvu Rapyta. Textos míticos de los Mbya-Guarani del Guairá. Asunción: Fundación "León Cadogan”/CEADUC/CAPAG, 1992a.

CADOGAN, León. Diccionário Mbya-Guarani -Castellano. Asunción: Fundación "León Cadogan"/ CEADUC/CAPAG, 1992b.

CASCUDO, Luís da Câmara. A literatura oral no Brasil. São Paulo: Global, 2006.

DAMÁSIO, António. $O$ erro de Descartes: emoção, razão e o cérebro humano. Tradução Dora Vicente e Georgina Segurado. São Paulo: Companhia das Letras, 1996.

FERREIRA NETTO, Waldemar. Os índios e a alfabetização. Aspectos da educação escolar entre os Guarani do Ribeirão Silveira. 1994. Tese (Doutoramento em Linguística) Faculdade de Filosofia, Letras e Ciências Humanas, Universidade de São Paulo, São Paulo, 1994.

FIORIN, José Luiz. A linguagem em uso. In: FIORIN, José Luiz (org.). Introdu̧ãa à linguística I. São Paulo: Contexto, 2002. p. 166-186. 


\section{Waldemar Ferrelra Netto}

GNERRE, Maurizio. Linguagem, escrita e poder. São Paulo: Martins Fontes, 1998.

GOFFMAN, Erwin. A representação do Eu na vida cotidiana. Tradução Maria Célia Santos Raposo do original de 1959, The presentation of self in everyday life. São Paulo: Vozes, 2005.

GOODY, Jack. Domesticaşão do pensamento selvagem. Tradução Nuno Luís Madureira. Lisboa: Presença, 1988.

GOODY, Jack; WATT, Ian. As consequências do letramento. Tradução Waldemar Ferreira Netto. São Paulo: Paulistana, 2006.

GRICE, H.P. Lógica e conversação. In: DASCAL, Marcelo (org.). Problemas, críticas, perspectivas da linguística. IV Pragmática. Campinas: Edição do Autor, 1982. p. 81-103.

HALBWACHS, Maurice. A memória coletiva. Tradução Laurent Leon Shaffter. São Paulo: Vértice/Revista dos Tribunais, 1990.

HAMANN, Stephan B.; ELY, Thimoty D.; KILTS, Clinton. Amygdala activity related to enhanced memory for pleasant and aversive stimuli. Nature Neuroscience, [S.l.], v. 3, n. 2, p. 289-293, 1999.

HOLLOWAY, Ralph. Human paleontological evidence relevant to language behavior. Human Neurobiology, [S.1.], n. 2, p. 105-114, 1983.

KAGAME, Aléxis. A percepção empírica do tempo e concepção da história no pensamento Bantu. In: RICOEUR, Paul (org.). As Culturas e o Tempo. Tradução Gentil Titton et al. Petrópolis: Vozes, 1975. p. 102-135.

KOCH-GRÜNBERG, Theodor. Mitos e Lendas dos Índios Taulipáng e Arekuná. Revista do Museu Paulista, São Paulo, Nova Série, n. 7, p. 9-202, 1953. [Tradução do 2º vol. de Vom Roraima zum Orinoco, Berlim, 1916, com exceção do prefácio e dos textos com tradução interlinear.]

KOCH, Ingedore V.; TRAVAGLIA, Luiz Carlos. Texto e coerência. São Paulo: Cortez, 1989.

LABOV, William. Some further steps in narrative analysis. The Journal of Narrative and Life History, [S.1.], v. 7, n. 1-4, 1997. [To appear in special issue]

LeGOFF, Jacques. A bistória nova. Tradução Eduardo Brandão. São Paulo: Companhia das Letras, 1990.

LEAKEY, Richard. A origem da espécie humana. Tradução Alexandre Tort. Rio de Janeiro: Rocco, 1997.

LINTON, Ralph. O homem. Uma introdução à antropologia. Tradução Lavínia Vilela do original de 1986, The Study of man: an introduction. São Paulo: Martins Fontes, 1981.

LOBATO, Monteiro. Fábulas e histórias diversas. 8. ed. São Paulo: Brasiliense, 1957.

MALINOWSKI, Bronislav. Magia, ciência e religião. Tradução Maria Georgina Segurado, da tradução em inglês, Magic, science and religion. Lisboa: Edições 70, [1988]. 
Tradição Oral e produção de narrativas

MARCUSCHI, Luiz Antônio. Da fala para a escrita. Atividades de retextualização. São Paulo: Cortez Editora, 2001.

McLUHAN, Marshall. Os Meios de Comunicação como Extensões do Homem. Tradução Décio Pignatari, do original de 1964. São Paulo: Cultrix, 1979.

MEGALE, H. (org.). Filologia bandeirante. Estudos 1. São Paulo: Humanitas/Fapesp, 2000.

MELO, Veríssimo de. Folclore infantil. Belo Horizonte: Itatiaia, 1979.

ONG, Walter. Oralidade e cultura escrita. Tradução Enid Abreu Dobránszky. Campinas: Papirus, 1998.

PEREIRA, Vera Lúcia F. O artesão da memória no Vale do Jequitinhonha. Belo Horizonte: Editora UFMG; Belo Horizonte: Editora PUC Minas, 1996.

PINTO, Maria Leda. Discurso e cotidiano: histórias de vida em depoimentos de pantaneiros. 2006. Tese. (Doutoramento em Filologia e Língua Portuguesa)-Faculdade de Filosofia, Letras e Ciências Humanas, Universidade de São Paulo, São Paulo, 2006.

REIS, Raul. The impact of television viewing in the brazilian amazon. Human Organization, [S.1.], v. 3, n. 57, p. 300-314, 1998.

ROSENFIELD, Israel. A invenção da memória: uma nova visão do cérebro. Tradução Vera Ribeiro. Rio de Janeiro: Nova Fronteira, 1994.

SAUSSURE, Ferdinand de. Curso de linguística geral. Tradução Antônio Chelini et al. São Paulo: Cultrix, 1977.

SCHOTT, Björn H.; HENSON, Richard N.; RICHARDSON-KLAVEHN, Alan; BECKER, Christine; THOMA, Volker; HEINZE, Hans-Jochen; DÜZEL, Emrah. Redefining implicit and explicit memory: The functional neuroanatomy of priming, remembering, and control of retrieval. PNAS, [S.1.], v. 4, n. 102, p. 1257-1262, 2005. SILVA, Fernando Correia da (org.). Contos indianos. Tradução Albertino Primeiro Junior et al. São Paulo: Ediouro, [19-].

TANGERINO, Celeste Ciccarone (org.). Revelações sobre a terra: a memória viva dos Guarani. Vitória: UFES, 1996.

VANSINA, Jan. La tradición oral. Tradução Miguel María Llongueras. Barcelona: Labor, 1966.

VANSINA, Jan. A tradição oral e sua metodologia. In: KI-ZERBO, J. (Org.) História geral da África: I. Metodologia e pré-história da África. Tradução Beatriz Turquetti et al. São Paulo: Ática; Paris: Unesco, 1982. p. 157-179.

VIEIRA, Domingos. O Grande Diccionario Portuguez ou Thesouro da Lingua Portugueza. Porto: Casa dos Editores Ernesto Chardron e Bartholomeu H. de Moraes, 1871-1874. 5 volumes.

XEDIEH, Osvaldo. Narrativas Pias Populares. Belo Horizonte: Itatiaia; São Paulo: Edusp, 1993. 


\title{
Ficha técnica
}

\author{
Mancha $10,5 \times 19 \mathrm{~cm}$ \\ Formato $14 \times 21 \mathrm{~cm}$ \\ Tipologia Garamond 3 Bt 12 e Gill Sans Mt Condensed 25 \\ Papel miolo: off-set $75 \mathrm{~g} / \mathrm{m}^{2}$ \\ capa: cartão supremo $250 \mathrm{~g} / \mathrm{m}^{2}$ \\ Número de páginas 104 \\ Tiragem 1.000 exemplares
}

